\title{
Contribuição para 0 Estudo Biológico e Ecológico das Podostemonaceae do Salto de Piracicaba
}

\author{
Walter Radamés Accorsi \\ Prof. de Botânica da E. S. A. \\ "Luiz de Queiroz", da Univer- \\ sidade de São Paulo
}

Introdução

Apinagia Accorsii Toledo

Produção de Estolhos

Frutos e Sementes

INDICE

Germinaçāo das Sementes

Embrião

Morfologia dos "Seedlings"

Tecido placentário e Reservas Nutritivas

Gemas Floriferas e seu Desenvolvimento

Desprendimento dos Caules

\begin{tabular}{l|lr}
59 & Dessecação dos Rizomas & 91 \\
67 & Polinização & 92 \\
71 & Mniopsis Glazioviana Warmg & 93 \\
73 & Placenta & 93 \\
73 & Sementes & 94 \\
76 & Embrião & 94 \\
76 & Descrição dos “Seedlings" & 96 \\
& Polinização & 97 \\
78 & Resumo e Conclusōes & 100 \\
& Summary & 104 \\
82 & Bibliografia consultada & 105 \\
85 & Pina
\end{tabular}

\section{I - INTRODUÇAOO}

As plantas da familia Podostemonaceae, hidrófitas herbaceas, em conseqüência da sua acentuada adaptação à vida aquática nas correntezas, cascatas e cataratas dos rios tropicais, constituem um dos mais interessantes grupos, dentre as

(*) Recebido para publicação no dia 4 de dezembro de 1944. 
Dicotiledôneas. Seus órgãos vegetativos são profundamente modificados e estão em correspondência com as condições d!) meio onde medram $(2,7)$. Por tais circunstâncias, assumem importância biológica e oferecem, também, interêsse ecológico.

Da sistemática das Podostemonaceae ocuparam-se RICHARD, MARTIUS, LINDLEY, SCHULTZ, MEISSNER, BONGARD, WEDDEL e outros (4). Dos tipos brasileiros incumbiu.• se o botânico francês LUIZ RENATO TULASNE, do Institutio de França (1). WARMING, em fins do século passado, publicou diversos trabalhos sôbre tão curiosa familia, levando en: consideração os aspectos sistemático e anatómico $(5,6)$.

Embora a posição sistemática da familia Podostemonaceae não esteja ainda bem definida, ela representa, contudo, um excelente campo de indagações biológicas e ecológicas, principalmente àquelas espécies que se mostram bem modificadas por influência do meio ambiente.

Nesta primeira contribuição, faço o estudo biológico e ecológico das espécies Apinagia Accorsii Toledo nov. sp. $\left(^{*}\right)$ e Mniopsis Glazioviana Warmg., que vivem no salto do rio Piracicaba, situado na cidade do mesmo nome. Dedico-me, principalmente, à primeira espécie, por ser a que revela maior transformação de tôda a parte vegetativa, ao lado de grande soma de caracteres de regressão, como a redução do sistema condutor, ausência de estômatos, a simplificação da estrutura to caule e das fôlhas, e preponderância da multiplicaçăo vegetativa (3). Vegeta, ainda, no mesmo habitat, a espécie Tristicha hypnoides (St. Hil.) Spreng. var. Halarii Tul. possivel que, numa exploração mais detalhada do salto, possam ser encontradas outras espécies de Podostemonaceae.

(") As plantas foram determinadas pelo botânico Joaquim Franco de Toledo. Chefe da Secção de Fitoteca do Instituto de Botânica do Estado de São Paulo, que fez, também, a diagnose e a descrição da nova espécie de Apinagia, as quais com a devida vênia, publico a seguir:

(") APINAGIA ACCORSII Toledo nov. sp. (an sect. Hymenolacis?) - Herba perennans, rhizomate repente depresso crasso, false dichotome ramoso-lobato, ab initio caules steriles ramosos emittente, dein deformiter incrassato et ramoso, tune post glutinationem cicatricium caulium delapsorum fasciculos florum ex gemmulis sopitis gerente; caulibus apice frondiformibus ramulosis multifido-capillaceis; foliis genuinis minimis, tantum quod ex innovationibus vix conspicuis, mox evanescentibus vel infra ramos inferiares raro persistentibus; spathellis alabastrique erectis, rarius incurvis; floribus pedicellatis 3-4-andris; capsulis saepissime 12-costulatis.

Planta satis robusta. Rhizoma arrhizum adspectu illius zingiberis officinalis, ad scopulos arcte adhaerens; ramificationibus brevibus sinuatis apice cmarginatis, ubi caules novellos scorpiodeos vel interdum stolones clongatos ramosos emittentibus; partibus junioribus supra, ut lineis pro- 
minulis notatis et alternatim dispositis, vestigium squamarum rhizomatis exhibentibus; dein, valde inodinatim conformatum et incrassatum, non raro ramulis superpositis sese anastomosantibus. Caules teretes alternatim dispositi ascendentes, longitudine maxime variabili, majores usque $30 \mathrm{~cm}$., basi plus minusve dilatati, false dichotome ramosi, internodiis longiusculis sed sursum sensim brevioribus, superne ut in axe principali ramis ramusculisque repetite in lacinias tenuissimas subdivisis instructi. Folia squamaeformia carnulosa pauca vel nulla ad partem superiorem caulis, sed illa innovationum axillarium ramusculiferarum arcte imbricata et gemmulas plus minusve globosas constituentia. Spathellae tubulosae subhyalinae, 5-10 $\mathrm{mm}$. longae, apicem versus dilatatae, ore 3-lobatae, lobis triangularibus acutis, ex fossis rhizomatis exserentes sed saepius deliquescentes. Flores demum erecti vel decumbentes, pediccellis (plane auctis) vulgo 3-3,5 $\mathrm{cm}$. longis et $1 \mathrm{~mm}$. crassis suffulti, in fasciculis 3-8-floris scorpioideo-dispositi; tepalis 5-6 membranaceis, anguste-lanceolatis, apice acutis vel raro bifurcis, ovarium aequantibus vel brevioribus; staminibus 3-4, ovario longioribus, filamentis subulatis 4-5 mm. longis, antheris luteolis oblongis apice obtusis, basi ca. 1/3 longitudinis amarginatis, $2-2,5 \mathrm{~mm}$. longis et 1 $\mathrm{mm}$. latis; ovario testaceo subnitido ellipsoideo vel ovoideo, $2,5 \mathrm{~mm}$. longo, stigmatis ramis basi brevissime coalitis plus minusve divaricatis, $2 \mathrm{~mm}$. longis. Capsulae fuscae ellipsoideae apice et basi acutiusculae, rarius 13-14costulatae, costulis obtusis, stigmatibus marcescetibus vel eorum basi coronatae, pedicellis capillaceis rigidis suffultae; semina numerosa minutissima ferruginea, ex compressione mutua angulata, texta subtillissime rugulosa.

Habitat ad scopulos cataractae "Piracicaba" prope urbem eodem nomine, in Provincia St. Pauli, Brasilia, ubi legit cl. W. R. Accorsi, 15-9-1943. Typus sub n. 48.947, in herbario Instituti Botanicae St. Pauli asservatus. Descriptio, ex specimine in liquido "alcoholico", elaboratur.

OBS. I - Habitu proprio distinctissimo, haec species maxime insignis est inter Apinagias, praecipue caulibus sterilibus ex rhizomate assurgentibus, demum delapsis; quum fasciculi florum ex gemmulis dormientibus unrumpet. Attamen planta Accorsiana cum Apinagia membranacea (Bong) Tul. comparada.

OBS. II - A Apinagia Accorsii Toledo caracteriza-se, principalmente. como planta relativamente robusta, possuindo um rizoma rastejante, achatado, grosso e ramoso-lobado, em conseqüencia de falsa dicotomia. A princípio êsse rizoma emite para cima caules estéreis e ramosos, tornando-se depois irregular, disformemente engrossado e ramificado. Os caules, com as extremidades frondiformes, ramulosas e capiláceo-multifendidas, são caducos ou marescentes depois de certo tempo. Junto às cicatrizes que deixam com a queda ou desaparecimento - as quais muitas vêzes são imperceptiveis e contribuem para a irregularidade acima referida - surgem os feixes de flores das gemas adormecidas. As verdadeiras fôlhas são muito reduzidas, mas podem ser perfeitamente constatadas nos brotos produtores de ramos; logo mais desaparecem com o crescimento dêstes, ou não raramente persistem sob a base dos ramos inferiores. As "espatelas" - ou conjunto de hipsofilas concrescidas num invólucro comum e tubuloso, protetor de botões - são, de regra, eretas como os últimos ou mais raramente curvas. As flores, sustentadas por pedicelos, possuem 3 ou 4 estames. As capsulas são ornadas por 12 nervuras longitudinais, raramente 13 ou 14 .

RIZOMA - Como os da maioria das Podostemonaceae, não possui raízes e adere fortemente à rocha, por incrustação. Pelo aspecto geral faz lembrar o de "gengibre", em proporções menores.. As ramificaçōes são curtas e arredondadas, dando-lhe o aspecto sinuoso ou lobado de que falámos; conseqüentemente, apresentam reentrâncias nas partes apicals, af 
onde dão formação a rebentos escorpioideos ou, mais raramente, estolhos compridos e ramificados, que também estão sujeitos a processos irregulares de tuberização. Nas partes novas providas de caules estéreis ainda intactos, pode-se observar, com freqüencia, os vestígios de escamas rizomácas, que apenas são perceptiveis sob a forma de saliências lineares pouco acentuadas e dispostas em zig-zag ou, mais precisamente, em disposição bisseriada e obliquamente um tanto imbricada. Finalmente, o rizoma adquire tal irregularidade que, muitas vêzes, ramos laterais superpondose a outros, anastomosanm-se como se houvessem aderido ao próprio substrato normal.

CAULES - São do tipo frondiforme, embora apresentem fôlhas legítimas escamiformes, geralmente bastante fugazes com 0 desenvolvimento dos brotos. A natureza frondiforme do caule nos é revelada pela subdivisâo em numerosas lacínias capiláceas, que se dá no próprio ápice da haste principal. A ramificação dística, que o caracteriza, apresenta-se sob a forma de uma falsa dicotomia, em conseqüencia do maior desenvolvimento de certos ramos e da flexão alternada que se opera na regiāo dos nós. Os entrenós inferiores são roliços e mais ou menos compridos, sendo o mais inferior implantado no rizoma em base geralmente bastante dilatada; os superiores são gradualmente mais curtos e menos roliços, até se tornarem comprimidos, mais para as extremidades Os últimos ramúsculos são fimbriados em segmentos tenuíssimos e comprimidos, dando, ao caule todo, o aspecto frondiforme já assinalado. Quanto às dimensões, variam os caules tanto em comprimento como em espessura; e encontramos alguns com 30 $\mathrm{cm}$. de comprimento. Mas, de regra, são sempre mais curtos.

FÓLHAS - São rudimentares e pouco numerosas, um tanto carnosas e hialinas, apresentando uma forma geralmente variável entre quase orbicular e abatido-triangular. A margem livre é levemente crenada ou crespa e a base de inserção é muito larga. Nos brotos novos normais ou adventícios sôbre os ramos velhos, adotam uma disposição imbricada e bisseriada, funcionando como verdadeiras pérulas protetoras e constituindo gemas mais ou menos globosas ou oblongas. Em geral, apenas persistem as fôlhas que dão origem aos primeiros ramos; tôdas as demais desaparecem com o crescimento do caule e ramos. As que perduram na base dos ramos inferiores nunca estão implantadas segundo um plano de simetria comum a ambos, mas sempre um tanto lateralmente no sentido dorsal do caule.

ESPATELAS - Sāo tubuloso-infundibuliformes e semitransparentes. com o ápice geralmente trilobado, e os lobos triangulares agudos e valvares na prefoliação. As espatelas formam-se em número variável (até cêrca de 8) em fossas do rizoma; desenvolvem-se sucessivamente, pelo que assinalam a natureza escorpioidea da inflorescência. As mais desenvolvidas contam-se entre $1 \mathrm{~cm}$. de comprimento $\mathrm{e}$ as menores, entre $1 / 2 \mathrm{~cm}$. Muitas delas são deterioradas antes do completo crescimento e apenas se evidenciam por resíduos dentro das citadas fossas.

FLORES - São sustentadas por pedicelos variáveis em tamanho, sendo os maiores com 3 até $3,5 \mathrm{~cm}$. de comprimento. A espessura é para todos de $1 \mathrm{~mm}$. Tais pedicelos são eretos ou decumbentes, conforme a localização sucessiva na inflorescência. As tépalas são membranáceas, estreito-lanceoladas, direitas ou mais ou menos flexuosas, agudas ou raramente bifurcadas no ápice. São em número de 5 ou 6 e as maiores chegam a atingir o ápice do ovário. Os estames em número de 3 ou 4, excedem o ovário em comprimento; possuem filêtes subulados com até 4 ou $5 \mathrm{~mm}$. de comprimento, sustentando anteras amareladas, oblongas, obtusas no ápice e chanfradas em cêrca de $1 / 3$ da base. com 2 a $2,5 \mathrm{~mm}$. de comprimento por $1 \mathrm{~mm}$. de largura. O ovário com côr de tijolo é um tanto lustroso, elipsoideo ou 
O salto de Piracicaba, devido à sua favorável situaçáo topográfica e às facilidades de acesso que apresenta durante todo o periodo de baixa do rio e mesmo no inicio da enchente, permitiu-me seguir o comportamento das espécies referidas, sob a variação do volume dágua e apreciar, "in loco", as fases do seu crescimento e desenvolvimento. Dest'arte, pude observar e registrar, durante pouco mais de um ano, tôdas as modificações e produções apresentadas pelas plantas, no de-curso dos ciclos vegetativo e floral, cujos resultados estão consignados nesta contribuição. Pretendo prosseguir, ainda, nesse terreno, coligindo observações que serão divulgadas futuramente, ao lado de um estudo anatómico dos òrgãos vegetativos e florais de Apinagia Accorsii Toledo.

O leito do rio Piracicaba, em tôda a região do salto, é formado de rochas diabásicas, que constituem o substrato apro. priado ao desenvolvimento das Podostemonaceae. Como acontece com substratos dessa natureza, em lugares semelhantes, - bloco rochoso possui uma configuração bem irregular, tanto em superfície como em espessura, produzindo o desdobramento da massa liquiida em inúmeras correntezas, cada uma com características próprias de volume, velocidade e arejamento.

ovoideo, com $2,5 \mathrm{~mm}$. de comprimento, encimado pelos dois ramos, um tanto divaricados, do estigma, os quais atingem $2 \mathrm{~mm}$. de comprimento.

CÁPSULAS - São escuras, elipsoideas, um pouco aguçadas na base e no ápice, com as nervuras relativamente largas, salientes e obtusas, algumas das quais não atingindo o ápice. As vêzes, as cápsulas são coroadas pelos estigmas ou apenas pela base concrescida dêstes. As sementes ferrugíneas, excesivamente miudas, são angulosas por compressão mútua e apresentam a testa finamente rugulosa. O aspecto capiláceo e rígido dos pedicelos capsulares tem origem pela desagregação do tecido cortical, pondo à mostra o cilindro central lenhoso.

Vive esta espécie nas rochas do Salto de Piracicaba, deante da cidade de igual nome, no Estado de São Paulo, Brasil, onde a coligiu W. R. Accorsi, em 15-9-1943. O tipo, sob n. ${ }^{\circ} 48.947$, encontra-se conservado no herbário do Instituto de Botânica de São Paulo. A descrição foi baseada em espécime conservado em solução alcoólica.

$\dot{E}$ espécie eminentemente distinta entre as Apinagiae, pelo próprio hábito peculiaríssimo e, principalmente, por possuir caules estérels que surgem do rizoma e depois caem ou murcham, quando então surgem os feixes de flores das gemas adormecidas. Entretanto, a planta de Accorsi deve ser comparada com Apinagia membranacea (Bong.) Tul., cuja descrição deixa transparecer afinidade, através das flores fasciculadas e cápsulas 12-nervadas. Nesta espécie, porém, o caule é dado como "frons crassa in membranam difformem irregularem, quasi fungosam et quoquoversus porrectam distendetur, etc.".

São Paulo, 18 de Abril de 1944.

J. F. Toledo

(Do Instituto de Botânica de S. Paulo) 
Por essa razão, tem-se, na mesma época e num só local, uma grande diversificação de meios, possibilitando, assim, uma apreciação melhor do comportamento das plantas sob a influência da variação dos fatores ambientais.

Para maiores esclarecimentos, junto os dados meteorológicos correspondentes ao periodo em que foram feitas as observaçōes (vide tabela), bem assim o início e duração das enchentes e vazantes do salto, expressos pela média de um período de 10 anos $\left(^{*}\right)$ (vide gráfico).

$\mathrm{Na}$ exposição do assunto, achei prudente conservar a ordem das datas em que foram feitas as observaçōes, cercadas das circunstâncias mesológicas ocorridas nas respectivas épocas. Dessa maneira, a apreciação do trabalho se torna mais fácil.

O autor agradece ao Prof. F. G. Brieger, da Escola Superior de Agricultura "Luiz de Queiroz., as sugestões e criticas apresentadas. O Prof. Brieger, segundo me informou, já havia recolhido, acêrca de quatro anos, algum material de Podostemonaceae do salto de Piracicaba.

Ao botânico Joaquim Franco de Toledo, do Instituto de Botânica do Estado, o autor consigna seus agradecimentos pela determinação das plantas de Podostemonaceae, bem como pela nimia gentileza com que se houve em denominar Apinagia Accorsii, a nova espécie de Podostemonaceae que vive no salto de Piracicaba.

(*) Os dadios que serviram de base à confecção do gráfico, que representa a média mensal durante o período de 1934 a 1943, da descarga em metros cúbicos por segundo do rio Piracicaba, em Carioba, foram cedidos gentilmente pela The Southern Brasil Electric Company, Ltd., a quem o autor agradece na pessoa do Dr. M. J. Nigro. 
Dados meteorológicos de agôsto de 1943 a Julho de 1944

\begin{tabular}{|c|c|c|c|c|c|c|}
\hline MESLE & Dias & $\begin{array}{l}\text { Altura } \\
\mathrm{m} / \mathrm{m}\end{array}$ & $\begin{array}{l}\text { Duraç̃o } \\
\text { Horas }\end{array}$ & 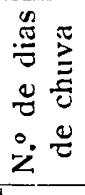 & 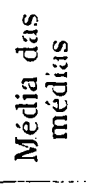 & 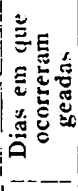 \\
\hline $\begin{array}{r}1943 \\
\text { Agôsto }\end{array}$ & $\begin{array}{rll}1 & \text { a } & 15 \\
16 & \text { a } & 31\end{array}$ & $\begin{array}{r}1,6 \\
11,9\end{array}$ & $\begin{array}{l}0,40 \\
3,10\end{array}$ & $\begin{array}{l}1 \\
2\end{array}$ & $\begin{array}{l}17,6 \\
18,7\end{array}$ & $\begin{array}{l}31 \\
-\cdots\end{array}$ \\
\hline Setembro & $\begin{array}{r}1 \text { a } 15 \\
16 \text { a } 30\end{array}$ & $\begin{array}{l}32,3 \\
40,7\end{array}$ & $\begin{array}{l}12,40 \\
16,45\end{array}$ & $\begin{array}{l}3 \\
5\end{array}$ & $\begin{array}{l}19,6 \\
19,5\end{array}$ & 15 \\
\hline Outubro & 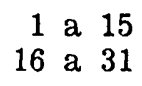 & $\begin{array}{l}108,1 \\
106,9\end{array}$ & & $\begin{array}{l}8 \\
6\end{array}$ & $\begin{array}{l}21,4 \\
22,1\end{array}$ & - \\
\hline Novembro & $\begin{array}{rrr}1 & \text { a } & 15 \\
16 & \text { a } & 30\end{array}$ & $\begin{array}{l}58,2 \\
96,1\end{array}$ & & $\begin{array}{l}4 \\
3\end{array}$ & $\begin{array}{l}24,0 \\
22,6\end{array}$ & - \\
\hline Dezembro & $\begin{array}{rll}1 & \text { a } & 15 \\
16 & \text { a } & 31\end{array}$ & $\begin{array}{l}141,9 \\
218,0\end{array}$ & & $\begin{array}{r}5 \\
10\end{array}$ & $\begin{array}{l}23,7 \\
21,4\end{array}$ & - \\
\hline $\begin{array}{c}1944 \\
\text { Janeiro }\end{array}$ & $\begin{array}{rll}1 & \text { a } & 15 \\
16 & \text { a } & 31\end{array}$ & $\begin{array}{l}62,3 \\
56,4\end{array}$ & & $\begin{array}{l}6 \\
8\end{array}$ & $\begin{array}{l}25,7 \\
23,6\end{array}$ & $\overrightarrow{-}$ \\
\hline Fevereiro & $\begin{array}{r}1 \text { a } 15 \\
16 \text { a } 29\end{array}$ & $\begin{array}{r}7,5 \\
207,7\end{array}$ & $\begin{array}{r}2,35 \\
54,13\end{array}$ & $\begin{array}{r}4 \\
11\end{array}$ & $\begin{array}{l}24,1 \\
23,6\end{array}$ & - \\
\hline Março & 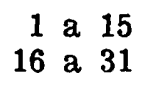 & $\begin{array}{r}150,6 \\
32,3\end{array}$ & $\begin{array}{r}18,40 \\
6,55\end{array}$ & $\begin{array}{l}7 \\
3\end{array}$ & $\begin{array}{l}24,4 \\
24,4\end{array}$ & - \\
\hline Abril & 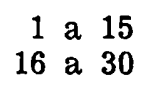 & $\begin{array}{l}10,9 \\
12,1\end{array}$ & & $\begin{array}{l}5 \\
3\end{array}$ & $\begin{array}{l}22,1 \\
20,6\end{array}$ & -- \\
\hline Maio & $\begin{array}{rrr}1 & \text { a } & 15 \\
16 & \text { a } & 31\end{array}$ & $\begin{array}{l}0,3 \\
0,6\end{array}$ & $\begin{array}{l}0,15 \\
0,30\end{array}$ & $\begin{array}{l}1 \\
2\end{array}$ & $\begin{array}{l}18,7 \\
18,4\end{array}$ & - \\
\hline Junho & $\begin{array}{rrr}1 & \text { a } & 15 \\
16 & \text { a } & 30\end{array}$ & $\begin{array}{r}3,1 \\
10,0\end{array}$ & $\begin{array}{l}1,20 \\
5,20\end{array}$ & $\begin{array}{l}1 \\
3\end{array}$ & $\begin{array}{l}17,0 \\
19,0\end{array}$ & - \\
\hline Julho & $\begin{array}{rrr}1 & \text { a } & 15 \\
16 & \text { a } & 31\end{array}$ & $\begin{array}{l}2,7 \\
0,0\end{array}$ & $\begin{array}{l}4,30 \\
0,0\end{array}$ & 2 & $\begin{array}{l}16,4 \\
17,4\end{array}$ & $\begin{array}{l}3 \\
4\end{array}$ \\
\hline TOTA] & & 1372,2 & 334,03 & 103 & 21,1 & 4 \\
\hline
\end{tabular}




\section{ESTUDO HIDROGRAFICO DO RIO PIRACICABA} EM CARIOBA

MÉDIA MENSAL DE 1934-1943.

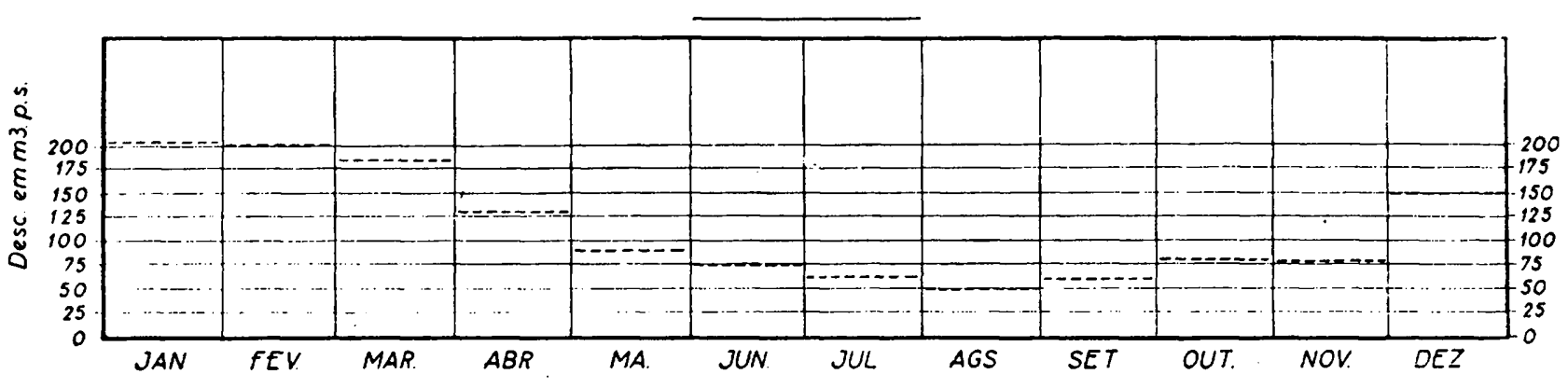




\section{2 - APINAGIA ACCORSII TOLEDO}

Em Agósto e princípios de Setembro de 1943, (antes da chuva intensa caida a 12-9-943, que determinou a queda de temperatura e a produção de geada a 15 de 9 ), o salto de $\mathrm{Pi}$ racicaba se apresentava com grande porcentagem de rochas expostas, em virtude da sêca prolongada que atravessamos. A baixa do rio começou em Maio. Pude observar, nessa ocasiãó, que a superficie exposta das rochas se achava recoberta de rizomas achatados, dessecados e alguns decompostos, de Apinagia Accorsii Toledo, trazendo, entretanto, grande quantidade de frutos do tipo cápsula, de cór marron, ovóides, supertados por um pedicelo (Fig. 8-c). Lembram, pela forma, os esrocarpos dos musgos. Em outras rochas, os frutos chegavam a cobrir superfícies enormes, parecendo nascer da propria pedra, uma vez que os rizomas achatados já se achavam completamente destruidos, em consequiência da prolongada exposição ao ar. Nas faces laterais das rochas banhadas pela água corrente, porém, com pouca velocidade, cresciam inúmeros rizomas verdes, achatados, em forma de placas, de superfície variável, contôrno irregular, assemelhando-se a talos de hepáticas (Fig. 4-e). Traziam grande produção de gemas floriferas (Figs. 6-7) e flores (Fig. 8-A) em tódas as fases de desenvolvimento. Encontrei, também, certa porcentagem de frutos. $O$ interessante é que determinados rizomas achatados apresentavam poucos caules novos; outros, entretanto, mostravam caules recém-produzidos e, finalmente, alguns rizomas despidos completamente. Todavia, as rochas situadas em tóda a extensão do declive, sob ação de forte correnteza (arejamento in. tenso) exibiam as superficies salientes completamente revestidas de Apinagia Accorsii Toledo, ricas de caules bem desenvolvidos, os quais se dividem, por seu turno, em caules secundários, terciários, etc., tendo o principal a curvatura voltada contra a direção da correnteza dágua (Fig. 1-c). As plantas colhidas nesse local traziam apenas caules grandes, ao lado de outros em vários estágios de desenvolvimento, porém, não possuiam nem flores e nem frutos. Nas extremidades dos callles existem numerosas expansões laminares, muito delgadas, longas e estreitas; são as lacínias capiláceas dos ramúsculos (Figs. 1, 2-a).

Os caules novos são de forma cônica, com gemas (Fig. 3) alternas e localizadas em sua porção extrema (Fig. 1-c-e). Em virtude da pouco resistência e da sua flexibilidade, os caules se inclinam sôbre a superficie dos rizomas achatados, na di- 


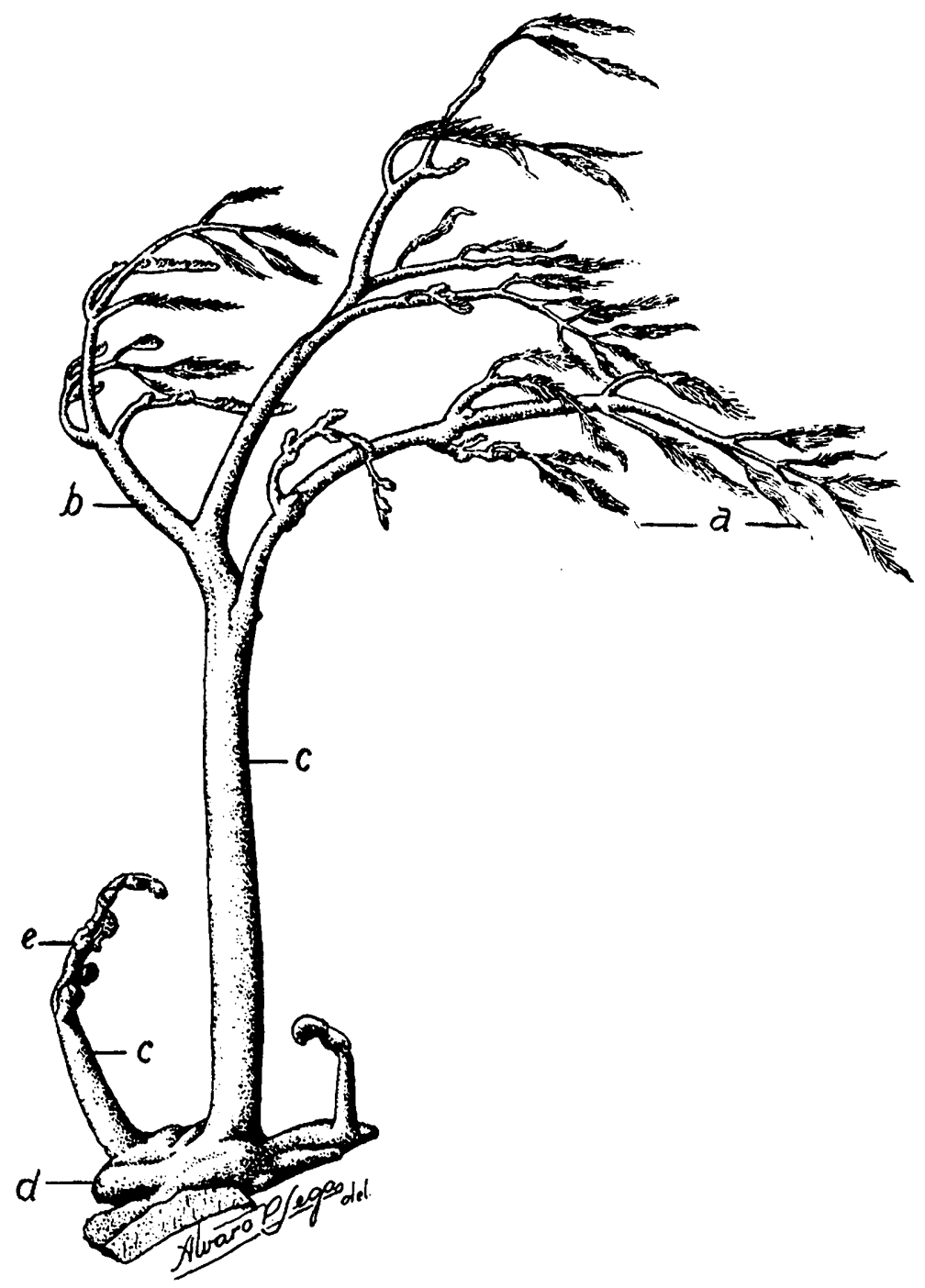

Fig. 1 - Fragmento de planta, em posição natural. Aumento 2x. (Original) a - lacínias capiláceas dos ramúculos; b - ramo secundário; c - haste principal ;d - rizoma achatado; e - gemas. 
reção da correnteze. Todavia; à medida que vão crescendo, se elevam e assumem a forma de arco, cuja convexidade avança contra a correnteza; os caules secundários, quando bem desenvolvidos, ostentam o mesmo aspecto do principal; de sorte que as extremidades e as respectivas lâminas filamentosas flutuam ao sabor das águas.

Das observações feitas na época citada, pude verificar que.

1 - nas rochas situadas em tóda a extensão do declive, submetidas, portanto, à ação continua da correnteza, em sua velocidade máxima, as plantas de Apinagia estavam abundantemente revestidas de caules, porém, não traziam flores e nem frutos.

2 - nas faces laterais das rochas localizadas nas proximidades da queda dágua, em lugar onde a correnteza é menos intensa, embora com desenvolvimento vegetativo igual ao das primeiras, as plantas produziam flores e frutos, e apresentavam apenas esboços de caules. Parece que essas diferenças de produção estão ligadas com o arejamento, velocidade e pressão da massa líqüida.

Tais plantas não se conservam fora dágua, por causa da dessecação que sofrem, em virtude da transpiração (verdadeira evaporação, porque, não possuindo estômatos, e com cutinização quase nula, a perda de água é um fenômeno puramente físico); logo depois, a planta começa a decompor-se, podendo entrar, mesmo, em putrefação. Ademais, a água que se precipita salto abaixo é fortemente arejada, por ser elevada a velocidade da correnteza nesse local. Aliás, a abundante espuma produzida pelo esboroar das águas de encontro às superficies pétreas, justifica plenamente tal asserção. $O$ arejamento se impõe, portanto, como uma das condições essenciais à vida das Podostemonaceae e, talvez, seja êle uma das causas que favorecem o desenvolvimento de tais plantas, em habitat tão peculiar, como sejam as quedas dágua.

Pude verificar, em laboratório, que a desintegração dos rizomas se iniciava nas camadas superiores (compreendendo o parênquima assimilador), cujos tecidos sofriam verdadeira dissociação celular. As células se separavam com muita facilidade, guardando, entretanto, a sua estrutura, conforme pude ave riguar ao microscópio.

As plantas de Apinagia Accorsii Toledo que ficaram expostas ao ar, recebendo sol direto, mostravam seus rizomas dessecados, com aspecto de crosta pardacenta. O interessante é 
que em alguns rizomas assim alterados se notava grande número de frutos, formando, às vêzes, densos agrupamentos, fortemente presos à superfície das rochas, de sorte que a sua extração só era possivel mediante o auxilio de uma lâmina bem afiada. Mesmo depois de umidecidos, quer pelas águas do rio, quer pelas chuvas, a fixação dos frutos mantinha-se firme e oferecia, ainda, enorme resistêcnia à extração.

Em 19 de Setembro de 1943, visitando o local, encontrel o mesmo aspecto acima descrito, apenas as águas haviam subido um pouco de nível, devido às chuvas caídas em 12 e 13 do mesmo mês.

Além da Apinagia Accorsii Toledo, cuja distribuição vegetativa abrange uma área compreendida por algumas dezenas de metros antes da queda dágua, até as primeiras rochas que se seguem ao declive, portato, em tôda a extensão do salto onde a velocidade, volume e arejamento da água são elevadissimos, encontrei a espécie Mniopsis Glazioviana Warmg., cujos frutos (Fig. 13-A), menores que os de Apinagia, lembram, também, os esporocarpos dos musgos, e a espécie Tristicha hypnoides (St. Hil.) Spreng. var. Hilarii Tul.. Nessa época do ano havia grande quantidade de frutinhos de Mniopsis fixados às pedras, estando a parte vegetativa completamente destruida, em conseqüência, talvez, de ter ficado fora dágua e recebido sol. Em outras rochas que permaneceram expostas por muito tempo, notei vestígios das plantinhas de Mniopsis que ali viveram, pois que, em sua superficie, estavam impressas faixas esbranquiçadas, longas, estreitas, bem sêcas e ramificadas, apresentando, aquí e acolá, séries de frutinhos marrons, curtamente pedicelados. Os mesmos vestígios foram encontrados em rochas situadas a, mais ou menos, 60 metros acima da cachoeira, nas proximidades da margem direita e em vários outros lugares.

A espécie Tristicha hypnoides (St. Hil.), var. Hilarii Tul. apresentava, nessa ocasiāo, flores de côr marron, sôbre raminhos longos, finos, bem ramificados e com fôlhas espiraladas.

Em 10 de Novembro de 1943 (periodo de chuvas), as águas do salto subiram de nivel, submergindo as rochas que, no inicio das minhas investigações, se achavam completa ou parcialmente expostas ao ar. Devo frizar que, a principio, observei sòmente o trecho do salto situado perto de um paredão de pedras, na margem direita do rio. Verifiquei, então, que as plantas de Apinagia desenvolveram notavelmente seus caules e ampliaram, sobremodo, seus rizomas, forrando completamente a superfície das pedras; tal crescimento se estendeu, também, à 
superficle lateral de algumas rochas que mostravam, no período de sêca, apenas alguns rizomas achatados, mas que, então, traziam inúmeros caules.

O interessante é que a produção de caules se deu abundalitemente nos rizomas que revestem as rochas situadas nos lugares onde a velocidade da correnteza é máxima. Não observei, nessa época, produçăo de flores, mas tão sòmente 0 desenvolvimento acentuado da parte vegetativa. Houve, também, aumento considerável de rizomas, pois, durante o período de sêca, o seu desenvolvimento era bem menor. Tôdas as rochas que se encontravam na zona do declive e que recebiarn fortes jactos dágua, estavam com suas superficies literalmente cobertas de caules novos e curvados, cujas extremidades acompanhavam a direção da correnteza (hidrotropismo negativo). Houve, por conseguinte, nessa fase da enchente, um intenso desenvolvimento vegetativo, isto é, crescimento dos rizomas e dos caules. Aliás, os caules foram encontrados, também, no período de águas baixas, porém, nos lugares de correnteza mais intensa; assim, as plantas de Apinagia que cobriam as rochas do declive, apresentavam caules. O crescimento vegetativo se relaciona com a velocidade, intensidade e are. jamento da massa dágua, realizando-se, por conseguinte, no periodo das enchentes, enquanto que a produção de flores ocorre quando as águas estão baixas. Anotel, ainda, o crescimento dos rizomas e a emissão de caules nos restos dos individuos que permaneceram nas rochas, após a colheita de material para estudo. Esse fato evidencia a possibilidade do crescimento e do desenvolvimento dos individuos remanescentes.

Em 15 de Novembro de 1943 , as águas baixaram mais que em 10 do mesmo mês, devido à falta de chuvas. Em conseqüêricia dessa pequena estiagem, houve maior exposição de rochas ao ar do que no dia 10, ficando a descoberto enorme quantidade de plantas de Apinagia que, até então, estiveram parcialmente submersas, exceção feita, naturalmente, aos seus caules, os quais, mesmo anteriormente, eram bem visiveis à flor dágua. Nessas condições, pude apreciar e avaliar o grande desenvolvimento vegetativo que as plantas de Apinagia realizaram, tanto em área (quase tôdas as rochas estavam cobertas por elas), como em produção de caules, desde o início do períndo da enchente.

\section{PRODUÇAO DE ESTOLHOS}

Nas faces laterais de algmas rochas que examinei com mais frequiência, devido à facilidade de acesso, encontrei numero- 
sos estolhos estreitos, hemicilindricos, aderentes à superficie cia pedra, longos e de coloração ligeiramente avermelhada (Fig. 5-f). Partiam de rizomas achatados, primitivos, como se fossem raízes (Fig. 4-c). Os estolhos emitem, alternadamente a dos seus flancos, novos rizomas (Fig. 4-a; Fig. 3-b), de tamanhos crescentes, a partir da sua extremidade. Dessa maneira fica assegurada a propagação vegetativa, pela produção de grande número de individuos. Cada pequeno rizoma lateral, começa a emitir, desde cedo, caules, tais como os exemplares já desenvolvidos .(Fig. 4-b; Fig. 5-d). Interesante é que os esto-

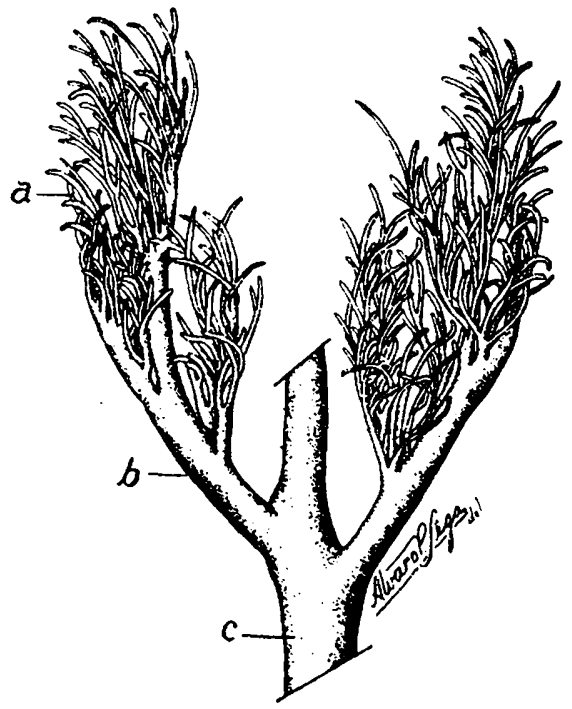

Fig. 2 - Segmento terminal de caule, muito aumentado. (Original).

a -.- lacínias capiláceas dos ramúsculos;

b... ramo secundário; c - haste principal.

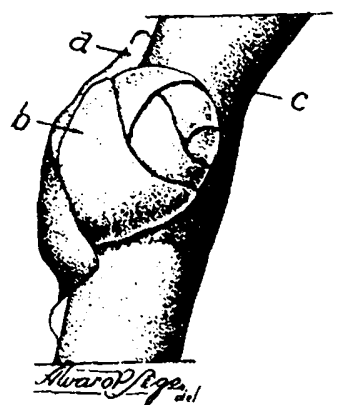

Fig. 3 - Gema ramifera, muito aumentada. (Original).

a - fôlha escamiforme, bastante fugaz; $b$ - pérulas da gema; c -- caule.

lhos, hemicilindricos, não produzem caules; seu papel consiste,apenas, em proporcionar um aumento de novos rizomas. A medida que os rizomas laterais crescem, separam-se do estolho primitivo e passam a constituir novos individuos. Em restos de rizomas adultos, que ainda permaneceram nas rochais após as raspagens que fiz pela primeira vez para colher mate- 
rial, pude verificar que também estavam emitindo estolhos enı várias direções. Parece que ao lado do desenvolvimento dos caules há, também, um desenvolvimento de novos individuos por via vegetativa, tudo isto se realizando no periodo da enchente. Havia notado nos primeiros rizomas, examinados eri principios de Agôsto, que a sua superficie, além de ser bem irregular, mostrava umas espécies de nervuras (que mais tardo se desenvolveriam em estolhos) (Fig. 4-f).

Nessa ocasiāo, não encontrei flores, porém, a quantidade de caules era grande - fase de crescimento vegetativo. Parece, pois, que os estolhos estão incumbidos da propagação vegetativa durante o periodo da enchente. Tal fato confirma, ainda, a hipótese de que a massa dágua aliada a outros fatores, age como um fator estimulante do crescimento e do desenvol.. vimento das plantas de Apinagia Accorsii Toledo, de vez que elas vivem em cachoeiras e revelam acentuado desenvolvimento na época das enchentes.

\section{FRUTOS E SEMENTES}

Os frutos são cápsulas elipsoidais, de coloração escura, com ápice e base ligeiramente aguçadas, providas de costulas; no ápice da cápsula se encontram, às vêzes, os estigmas murchos ou, então, apenas as bașes concrescidas dêles. As cápsulas sã.o sustentadas por pedicelos capiláceos e rigidos (Fig. 8-c; Fig. 10).

As sementes são ferrugineas e excessivamente pequenas, medindo 405 micra de comprimento, por 234 micra de largura (média de várias mensurações). A testa é sutilmente rugulosa. (Fig. 9-B).

\section{GERMINAÇĀO DAS SEMENTES}

Em 16 de Novembro, ao examinar o material colhido, encontrei, com bastante surpresa, vários frutos contendo em seu interior sementes em germinação, e mesmo alguns "seedlings" bem desenvolvidos (Fig. 11) de Apinagia Accorsii Toledo. Achei. ainda, grande quantidade de cápsulas de Mniopsis Glazioviana Warmg. cobertas de "seedlings" que provinham do interior dos frutos parcialmente deiscentes (Fig. 15). As sementes germinaram, pois, dentro dos frutos, como no caso de Apinagia. Algumas cápsulas estavam literalmente revestidas de "seedlings", a-ponto-de dar a impressão de um conjunto de fólhas suportadas por um pedicelo. Além disso, colhi abundante material composto de restos de partes vegetativas de Mniopsis, inclusive 


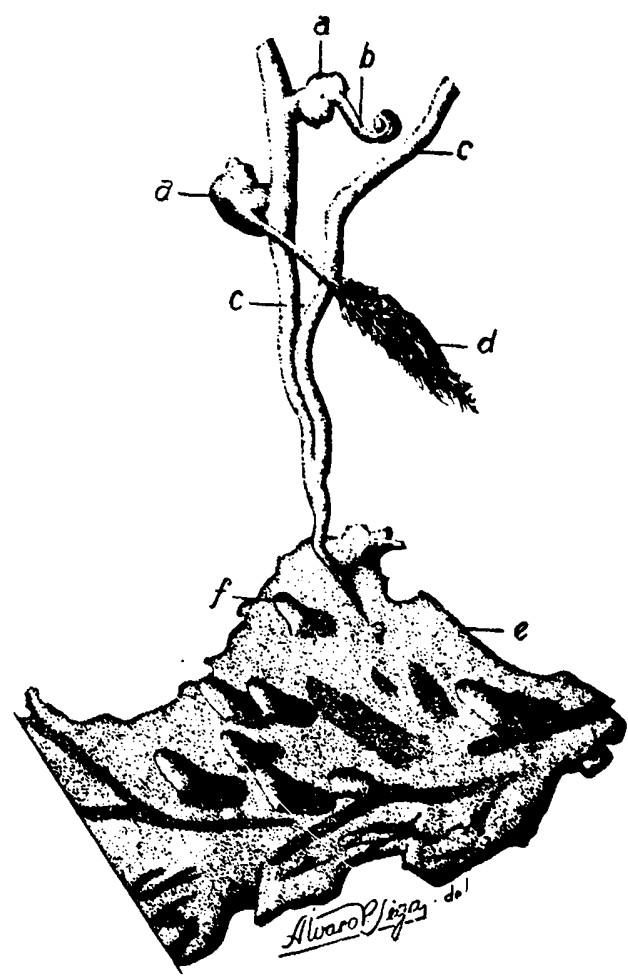

Fig. 4 -. Rizoma com produção de estolhos. Aumento $1,5 \mathrm{x}$. (Originai).

a - rizoma em desenvolvimento; b - caule jovem; c - estolho; d - lacínias capiláceas dos ramúsculos; e - rizoma adulto; f - estolhos em formação.

frutos ainda fechados, apresentando certa porcentagem de "seedlings", o que demonstra a possibilidade de as sementes poderem germinar, também, em ambiente externo (Fig. 14). Nas plantinhas de Mniopsis se destaca, logo, uma raiz, de cujos flancos nascem formações foliáceas.

As rafzes de Mniopsis, como os estolhos de Apinagia, mostram dorsiventralidade.

Em virtude de ser a propagação por sementes comum às duas espécies, trato, neste capítulo, do assunto em conjunto.

A passagem das plantinhas da superfície do fruto, onde se 
desenvolveram, para a pedra onde deverão crescer, pode ser explicada assim: o pedicelo dos frutos de Mniopsis é, em geral, muito curto, com poucos milimetros de comprimento, de modo que as plantinhas fixadas na cápsula, quando atingirem certo desenvolvimento, se encostarão com facilidade na rocha, cuja superfície áspera favorece a aderência das raizes. Ademais, os frutos, quando são parcialmente submersos ou, então, umidecldos pela correnteza, teem seus pedicelos mais flexiveis, e, sob a ação da pressão dágua, curvam-se, permitindo que as cápsulas venham a encostar-se à superfície da rocha, processandose a fixaçăo definitiva das jovens plantas. ser observados "in loco". Comportamento identico verifica-se com inumeros frutos de Apinagia, mormente nas faces laterais de algumas pedras. Na hipótese de os seedlings" se desprenderem dos frutos, ficarāo retidos entre os caules ou nas reentrâncias dos rizomas achatados, onde se fixarăo; aliás, a presença de várias plantinhas sôbre os caules, rizomas, etc., confirma tal asserçăo.

Em 23-11-943, o rio estava bastante baixo, pois não chovia havia vários dias. Na face de uma rocha banhada pelas águas encontravam-se inúmeros frutos de Apinagia, deitados sóbre a superfície e presos, ainda, pelo pedicelo. Sóbre as cápsulas havia algumas plantinhas desenvolvidas, com o rizoma bem constituido e vários caules novos. evidente que a plantinha, aumentando de pêso, em virtude do seu desenvolvimento, e devi do à flexibilidade do pedicelo, obrigue a cápsula a encostar-se à superficie da rocha, à qual, pouco a pouco, o rizoma vaí ade.. rindo.

Os "seedlings", desde as primeiras fases do desenvolvimento do embrião, são verdes, portanto, capazes de elaborar a síntese das substâncias orgánicas, pois na água sempre há, em dissolução, elementos necessários à vida das plantas. Ademais, nessa época do ano, as águas do rio estão carregadas de elementos minerais provenientes da lavagem dos solos, de modo que as Podostemonaceae podem realizar, com maior intensidade, o crescimento vegetativo.

Digno de nota é o fato de o rizoma, à medida que vai crescendo, englobar a cápsula, que fica, assim, completamente ernbutida no seio dêle, dando, muitas vêzes, a impressão de que as plantinhas săo providas de um pedicelo. Dessa maneira se explica a propagação por sementes de Apinagia Accorsii Toledo e de Mniopsis Glazioviana Warmg. no local onde vivem, processo bastante interessante. Naturalmente, as plantinhas podem desprender-se do fruto, onde se realizou a germinaçăo da semen- 
te, e fixar-se em outra parte, como no pedicelo, ou, ainda, sôbre os rizomas adultos dos individuos que vivem nas imediações, conforme atestam os numerosos exemplos encontradns. Todavia, o caso mais geral que talvez seja o processo natural da biologia de tais plantas, é o de que a germinação da spmente e as primeiras fases do desenvolvimento das plantinhas se realizem no interior do fruto (Figs. 11-12) que, não só ofere-ce as condições de proteçăo necessárias à garantia do crescimento das jovens plantas num meio tão instável, qual seja unia queda dágua, como proporciona ao embriáo os alimentos armazenados na placenta, uma vez que as sementes são desprovidas de endosperma.

\section{EMBRIAOO}

De tamanho microscópico, o embrião mostra uma configuração simples, mais se parecendo a um U bem fechado, cujos ramos pontudos são os cotilédiones. Não se distinguem radícıla e caulículo, constituindo a volta ou arco do U o hipocótilo (Fig. 9-A e C). Na maturadidade da semente e por ocasião da sua germinação, o embrião é esverdeado.

\section{MORFOLOGIA DOS "SEEDLINGS"}

Conforme já assinalei, as sementes das espécies de Podostemonaceae em estudo germinam, em geral, dentro do fruto e sôbre a placenta (Figs. 11-15); todavia, a germinação pode efetuar-se, também, em meio exterior, sôbre as amplas e anfratuosas superfícies rizomáticas, nos detritos e restos vegetais que se acumulam entre os caules de Apinagia, bem como nas paredes externas das cápsulas e nos pedicelos dos frutos, etc.. Foi nesse meio que encontrei numerosos "seedlings" em pleno desenvolvimento, sempre fixados sôbre o substrato. óbvin, entretanto, que o meio exterior não pode oferecer as mesmas probabilidades de éxito para a garantia da germinação, como as apresentadas pelo interior do fruto, em virtude das razões apontadas.

Os "seedlings", que nesse estágio são bem clorofiladñ̆, mostram os dois longos cotilédones (720 micra de comprimento por 112,5 de largura, a região de inserção do eixo hipocótilo levemente recurvados (Fig. 12). Continuam a apresentar a mesma configuração de $U$ do embrião, de ramos longos (cotilédones) e juxtapostos, cujas extremidades são bem afiladas. O hipocótilo, constituido de radícula e caulículo morfologicamente indistintos, ocupa todo o vértice engrossado do 


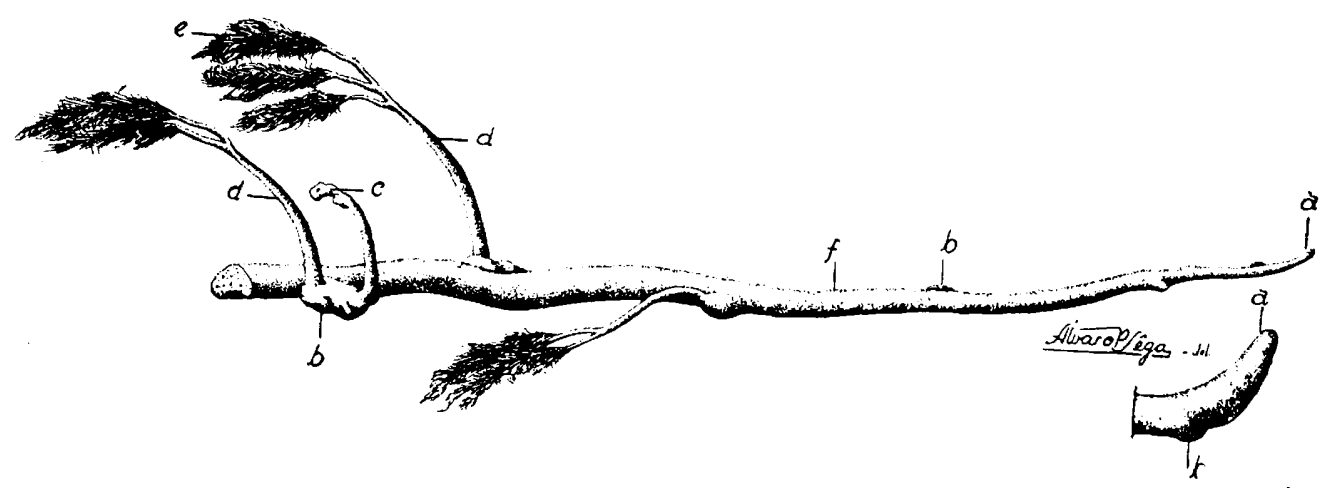

a - ápice vegetativo do estolho; b - rizomas em desenvolvimento; c extremo de um caule novo. frondiforme; d - caules jovens: e - lacínias capiláceas dos ramúsculos; $\mathrm{f}$ - estolho. 
$\mathrm{U}$, e tem 225 micra de largura por 180 de comprimento. Um tufo denso de longos pélos (360 micra de comprimento) unicelulares cobre tôda a superfície adstrita à curva do $U$.

Os "seedlings" parecem ser constituidos inteiramente de parênquima clorofiliano, porém, de células estreitamente unidas entre si, isto é, sem meatos; apresentam, em secção ótica, forma poligonal. Revestindo o parênquima clorofiliano, vem uma epiderme formada de uma camada de células, bem juxtapostas, exibindo seç̧ão retangular. A epiderme contém, também, cloroplastídeos; não possui cutícula, nem estômatos.

Năo pude distinguir no seio do parênquima clorofiliano organização de feixes libero-lenhosos, sendo, pois, simples a estrutura dos "seedlings". Em linhas gerais, êsse é o aspecto morfológico dos "seedlings" em sua primeira fase de desenvolvimento.

\section{TECIDO PLACENTARIO E RESERVAS NUTRITIVAS}

Em virtude de grande parte da germinação das sementes se operar no interior do fruto e sôbre a placenta (ver desenhos) e, pelo fato de as mesmas não possuirem endosperma, fui levado a investigar a natureza do tecido placentário, mesmo porque, a placenta se apresenta bem desenvolvida, de forma ovóide e se mostra esverdeada. O tecido placentário é de natureza parenquimatosa, em cujas células existem cloroplastídeos, de forma aproximadamente esférica.

No parênquima placentário dos frutos novos encontram-īe, a princípio, apenas cloroplastos, faltando os grăos de amido, Por essa razáo, a cór da placenta é de um verde intenso. Com o progredir da maturação do fruto e das sementes, percebe-se a formação de amido no interior dos cloroplastos, o que pode ser demonstrado prontamente pela reação de Lugol, ou pelo exame microscópico; ademais, a coloração verde da placenta vai se tornando menos pronunciada. Numa fase de maturação mais adeantada, os ggrãos de amido estão completamente formados, consistindo de tipos simples e alguns compostos de 2 , 3, 4 e mesmo 5 grăos. Os grãos de amido são pequeníssimos; suas dimensões variam entre 5,1 e 5,2 micra para os menores e 10,8 micra para os maiores. A forma é variável; alguns se assemelham aos grăos de amido do trigo, outros, aos da mandioca. Contudo, os maiores são praticamente lenticulares. O hilo é central e fissurado, podendo ser simples ou ligeiramente ramificado; às vêzes, assume o aspecto de uma pequena depressão. A luz polarizada, há formação da figura de in- 
terferência, característica do amido; a intersecçăo dos braços da cruz coincide com a regiăo do hllo.

Fica esclarecido, assim, mais um detalhe curioso das Podostemonaceae, isto é, que o fruto, além de constituir as condiçes necessárias para a germinação das sementes, possui, alnda, a placenta com reservas nutritivas para a alimentação do embriāo, até que a plantinha possa conseguir a sua independência fisiológica. Ademais, o embrião possui cloroplastos desde as fases iniciais da germinação da semente, podendo, por conseguinte, realizar a fotossintese. por essa razão que os embrióes podem desenvolver-se, também, em outros substratos.

o parênquima cortical do pedicelo da flor também possui notáveis reservas de amido, de aspecto idêntico ao encontrado na placenta. Mais tarde, o parênquima cortical se destroi, per.manecendo apenas o cilindro central, que funciona como pedicelo do fruto. No tegumento das sementes, cujas células são grandes e de paredes finas, há, também, grãos de amido simples e compostos, em grande número, da mesma forma e tamanho dos já assinalados.

As placentas são volumosas, de forma ovóide, ocupando posição central no fruto; pela base se fixam no ponto de in. serção do pedicelo na cápsula (Fig. 10). Desempenham, pois, o papel de órgãos de reserva, em virtude do que ficou exposto, e da presença de "seedlings" fixados em seus tecidos, por meio dos pêlos absorventes (Fig. 11).

Os pêlos absorventes, que se formam em grande número na extremidade do hipocótilo (Fig. 12-c), funcionam como haustórios se os "seedlings" se desenvolvem sôbre a placenta, porque, então, se introduzem no parênquima placentário de onde retiram as reservas nutritivas, ou desempenham, apenas, o papel de elementos de fixação, se a germinação se der no meio exterior. Allás, colhi "seedlings" de ambas as espécies dẹ Podostemonaceae, desenvolvendo-se muito bem sôbre rizomas, caules, etc., de Apinagia, e, ainda, em restos vegetativos de Mniopsis, bem como em detritos orgânicos existentes no meio ambiente. No primeiro caso, haveria uma espécie de semiparasitismo, pois que os "seedlings" clorofilados estăo vivendo à custa de um tecido vivo. Por outro lado, tenho encontrado seedlings" fora dos frutos, presos aos ramos, aos rizomas achatados e mesmo em restos de vegetais, o que atesta a possibilidade de sua independência fisiológica.

Em 9 de Dezembro de 1943, visitei o salto pela manhã; 

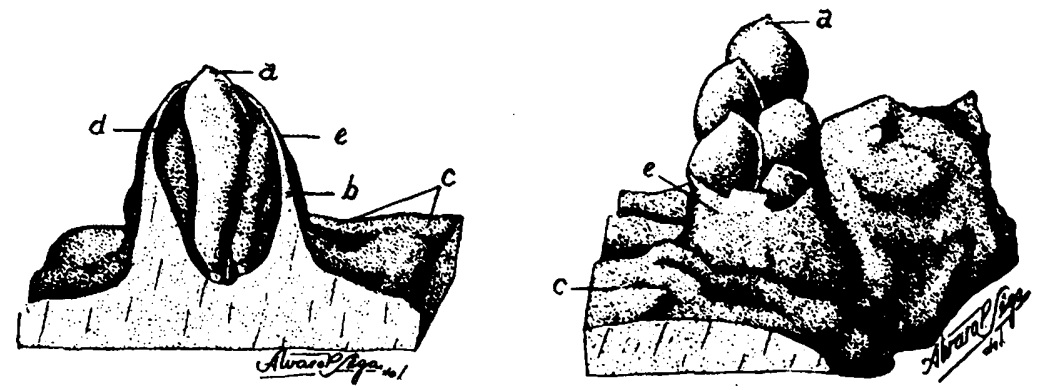

Fig. 6 - Gema florífera, em corte longitudinal, bem aumentada. Fig. 7 Gema desabrochada, mostrando 5 flores, bem aumentada. (Originais). a -- flor envolta na espatela; b - parede da escama; c -- rizoma: d interior da gema (câmara florifera); e -- escama.

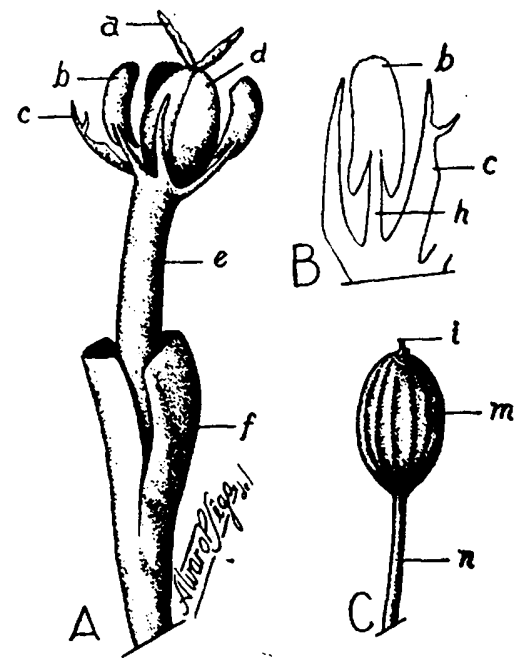

Fig. 8 - Flor (A) e estame (B), mui(1) aumentados. Fruto (C), aumentado $4 \mathrm{x}$. (Originais).

a - estigma; b - antera; c - tépalas membranáceas; d - ovário; e pedicelo da flor, provido de córtex; f - espatela; $h$ - filête; $\mathrm{j}$ - estigma dessecado; $m$ - parede da cápsula; $\mathrm{n}$ - pedicelo. 
águas baixas, muitas rochas expostas, com grande quantidade de plantas de Apinagia que se achavam, nessa ocasião, com grande desenvolvimento de caules; êstes, quando em contacto com a atmosfera, porém, banhados constantemente pela correnteza, apresentavam aspecto normal, ao passo que os que estavam fora da ação da água se mostravam pardacentos por cusa da ação dos raios solares e da evaporação. Aliás, as plantas de Apinagia não resistem em outro meio que não seja o $\mathrm{d}: \mathrm{z}$ água corrente e arejada, conforme pude deduzir das observações feitas em laboratório, no próprio salto, e em lugares que permaneceram sécos por vários dias. Procurei conservar algu.mas plantas em água parada, sem conseguir, contudo, resultado positivo, a-pesar-da renovação contínua do meio; a decomposição logo se iniciava, mesmo no caso da Apinagia estar aderente à pedra. Em vista da sêca ocorrida ocasionalmente durante vários dias, num mês chuvoso, como o de Dezembrn, quando o salto já devia estar cheio, grande parte da superficie das rochas ficou exposta ao ar, permitinao-me verificar, em extensa área, o enorme desenvolvimento realizado pelas plantas de Apinagia.

Em 30 de Janeiro de 1944, a 9 e 16 de Fevereiro, visitei o salto. As águas estavam baixas, em virtude de uma pequena estiagem; por essa razão, apreciável quantidade de rochas re. cobertas de Apinagia, em pleno desenvolvimento vegetativo, se expoz à atmosfera. Períodos assim, isto é, águas baixas ern fins de Janeiro e começos de Fevereiro, não são comuns, por ser precisamente nessa época que o salto se apresenta em plena fase de enchente. Estas variantes do meio ambiente são importantes, pois permitem apreciar o crescimento e o desenvo!vimento realizado pelas Podostemonaceae, o que seria muits dificil, de outra forma, porque as plantas deveriam estar completamente submersas. Nas faces de diversas rochas voltadas para o nascente houve acentuado crescimento vegetativo, tan to de rizomas achatados como de caules, inclusive boa produção de estolhos providos de rizomas em formação.

$O$ gênero Mniopsis encontra-se, também, em pleno desenvolvimento vegetativo, emitindo, por sua vez, raizes hemiciliridricas (Fig. 17), em grande número e em várias direções. Por conseguinte, a exposição temporária das rochas veio mostrar que durante o período de enchente as Podostemonaceae realizam o crescimento vegetativo.

O maior desenvolvimento de Apinagia se deu nas rochos situadas no declive da queda dágua e nas primeiras rochas contíguas, onde a produção de caules era deveras enorme. 
Em 25-2-944, após um período anormal de sêca, ocorrido em plena época das águas, seguiram-se dias a-fio de chuvas; o nivel do rio elevou-se, submergindo, outra vez, as plantas de Apinagia.

Durante o mês de Março, as chuvas foram pouco abundantes, exceção dos primeiros dias; a última chuva ocorreu a 193-944. Nestas condições, as águas do salto baixaram, expondo ao ar, outra vez, as Podostemonaceae; a distribuição de Apinagia Accorsii Toledo, na superfície das rochas (faces laterais e superiores) era bem grande, sendo, entretanto, maior na zona da queda dágua.

Em fins do mês de Abril, as águas do salto começaram a declinar de volume devido às poucas chuvas caidas ultimamente (o periodo de baixa do rio já começou), descobrindo novamente grande porcentagem de rochas, as quais exibiam denso revestimento de Apinagia Accorsii Toledo, formado durante o favorável período da enchente, revelando, ainda, notável desenvolvimento de caules. As plantas completaram nessa fase o seu crescimento vegetativo e alcançaram a maior distribuição em área no seu habitat. Assim, as rochas pareciam atapetadas por um imenso manto verde (rizomas), densamente provido de franjas (caules).

Em 27-4-944 observei que as plantas de Apinagia Accorsii Toledo situadas nas rochas parcialmente expostas, havia alguns dias, devido à baixa do nivel dágua, se encontravam am franco periodo de florescimento e de frutificaçção (Fig. 8-A-(), havendo, ainda, sôbre os novos rizomas (formados durante 0 periodo da enchente) largamente achatados, numerosas gemas floriferas, em diversos estágios de desenvolvimento, distribuidas irregularmente; localizam-se, com freqüência, nos bordos do rizoma, que lembra, pelo aspecto de conjunto, uma pequena maquete de terreno, de configuração acidentada, cheio de colinas.

\section{GEMAS FLORÍFERAS E SEU DESENVOLVIMENTO}

As gemas floriferas formam-se no seio dos tecidos do rizoma, onde ocupam tôda a espessura compreendida entre as suas faces superior e inferior (Figs. 6-7). A medida que se desenvolvem, vão se salientando na superfície do rizoma, e adquirem o aspecto cônico já assinalado; em sua constituição per. cebem-se duas escamas carnosas, concrescentes pelos bordos laterais, sendo as partes terminais mais aelgadas e de disposição embricda. Uma linha sinuosa no dorso da gema confir- 

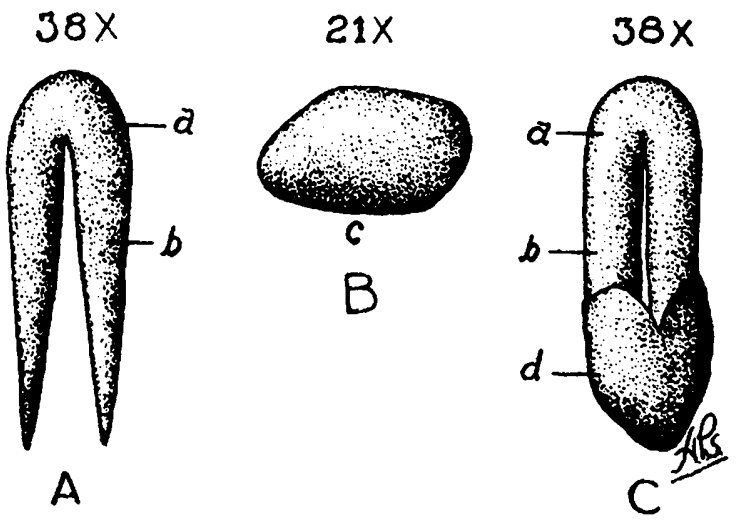

Fig. 9 - Embrião isolado (A); aumento $38 \mathrm{X}$.

Semente (B); aumento $21 \mathrm{X}$. Semente em germinação (C); aumento $38 \mathrm{X}$; (Originais). a - hipocótilo; b - cotilédones; d -- tegumen-

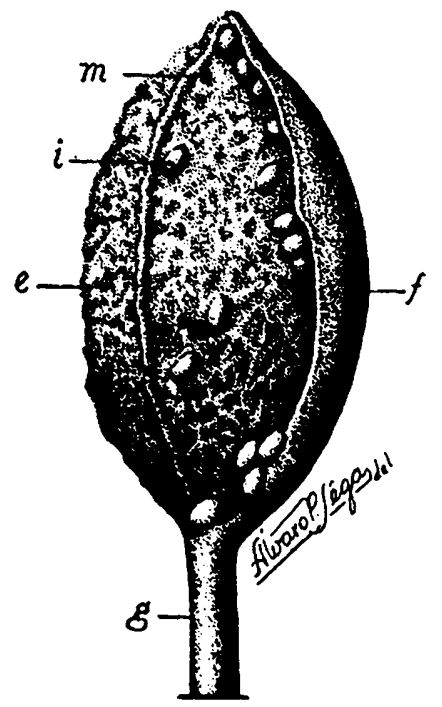

Fig. 10 - Fruto sem um dos opérculos. Aumento $17,5 \mathrm{X}$. (Original).

e - placenta; $\mathbf{f}$ - parede da cápsula; $\mathrm{g}$ - pedicelo; i - semente. 
ma tal estrutura. Freqüentemente, encontram-se sôbre os flancos de cada escama (pérula) um caule, cuja inserção pode tar no centro ou na base da escama; em geral, êsses caules jovens não chegam a se desenvolver completamente, devido 20 afastamento posterior das escamas ou, então, por causa da sua destruição parcial, por ocasião da abertura das mesmas. As gemas abrigam, em média, de 3 a 5 flores; estas se inserem, pa.. los seus pedicelos, na base da câmara florifera (interior da gema), que, por sua vez, está em contacto com a face do rizoma que adere às rochas (Fig. 6). Esta inserçção é importante, pois garante a fixação dos frutos na rocha, após a dessecação do rizoma.

A abertura (desabrochar) das gemas se dá em conseqüencia da pressão interna exercida nas escamas pelas flores em pleno crescimento, principalmente pela maior, a qual, um tallto recurvada, aplica-se diretamente na região onde os bordns livres das escamas se imbricam; dêsse modo, uma fenda mais ou menos elíptica, que se alarga progressivamente, surge no cimo da gema, através da qual, pouco a pouco, passam as flores em seu crescimento. Mais tarde, as câmaras onde se formaram e desenvolveram as flores, se constituem nas fossas do rizoma. As plantas florescem e frutificam unicamente em contacto com a atmosfera.

Observando as plantas de Apinagia Accorsii Toledo ainda submersas, nessa ocasião, verifiquei que a superfície dos rizomas apenas exibia um aspecto rugoso, em virtude das inúme.ras gemas floriferas, tôdas fechadas, mas em vários estágios de desenvolvimento.

Parece, pois, que sob as novas condições de meio, a floração e a conseqüente frutificação são aceleradas, assegurando a perpetuação da espécie no local. Aliás, dessa época em diante, os rizomas estarão sujeitos a uma constante dessecação, devido ao período de baixa do rio estar em andamento. As plantas perdem, contínuamente, água por evaporação, embora recebam, de vez em quando, jactos das correntezas que se chocam contra as rochas e a-pesar-de ser elevado o grau higrométrico da atmosfera, nas vizinhanças das Podostemonaceae parcialmente expostas. Corroborando essa hipótese estão os rizomas novos, recém-formados pelos estolhos durante o período de baixa, com suas gemas floriferas abertas, ostentando flo. res e mesmo frutos. Ademais, a ação direta dos raios solares durante grande parte do dia, concorre para aumentar a dessecação e a posterior destruição das plantas que estão em contacto com a atmosfera. Dessa maneira, aos poucos, tôda a parte 
vegetativa de Apinagia Accorsii Toledo (rizomas, caules, etc.), vai murchando e se destruindo, ficando apenas os frutos pre. sos à rocha pelos pedicelos, pois, conforme já assinalei; as flores se fixam à base da câmara florífera, bem em contacto conı as rochas. Assim, ficam os frutos implantados sôbre as pedias, durante todo o periodo de baixa do rio, até que, no inicio das novas enchentes, se dê a germinação das sementes, segundo o processo já explicado.

\section{DESPRENDIMENTO DOS CAULES}

Nesta fase do desenvolvimento das plantas de Apinagia Accorsii Toledo em grande parte expostas, observa-se, em vários indivíduos, o despredimento dos caules flutuantes, princjpalmente os que se acham sob a ação contínua da correnteza. Fato semelhante mostram as plantas semiexpostas e que recebem, ainda, jactos intermitentes dágua. Na região básica dos caules percebe-se que os tecidos se estão dilacerando em grande extensāo, ora em sentido longitudinal (parecem lanhados). ora em sentido circular, ora na zona de inserção com o rizoma ou um pouco mais acima; o mesmo fenómeno ocorre, ainda, nas subdivisões dos caules, isto é, nas imediações dos nós dos ramúsculos. A desintegração dos tecidos parenquimatosos da zona básica dos caules aumenta gradativamaente; na fase quase final dêsse processo, apenas os feixes vasculares, cuja ruptura pode dar-se a qualquer momento, ligam os caules ao rizoma. Bem antes da queda, os caules perdem as extremidades frondiformes ramulosas e capiláceo-multifendidas.

Sóbre o rizoma ficam, então, as cicatrizes caulinares, de côr clara a principio, cuja forma em geral é circular, mostrardo um número variável de pontuações correspondentes aos feixes vasculares. Mais tarde, com a cicatrização da ferida, ainda se percebem os vestígios dos feixes vasculares. No caso de o rompimento dos caules se dar acima da superfície do ri.zoma, o tôco remanescente vai, aos poucos, se desgastando, até desaparecer quase por completo. Dest'arte, a superficie do rizoma fica mais irregular, em conseqüência dos restos caulinares.

Parece provável que a causa principal da ruptura dos caules, além de outras que serão oportunamente investigadas, seja a constante vibração a que estão submetidos, porque ,nessa ocasião, estão flutuando (ao passo que na fase de submersão êles são estirados continuamente pelas águas, mormente quando o rio está meio alto) de modo que a região basal suporta os 
efeitos de uma espécie de torsão constante, provocando, entăo. a dilaceração dos tecidos. O comportamento referido dos caules flutuantes e dos submersos, que vivem na região da correnteza, poude ser observado repetidas vêzes, "in loco". Contudo, nem sempre êles se desprendem dos rizomas, pois, em plantas onde o fenómeno se verifica, há muitos caules que, devido à sua situação e vigor mais acentuado que os outros, năo se destacam, nem revelam destruição dos tecidos nos pontos assinalados. Ademais, nessa época, uma grande parte da superfície das rochas está completamente fora dágua e fora do alcance das ondas, de sorte que os caules estarão sujeitos a uma posterior destruição por dessecação, assim como os rizomas. Allás, já é bem visível um amarelecimento geral nas plantas de Apinagia Accorsii Toledo que vivem fora dágua.

A direçăo dos caules principais é determinada pela própria direção da correnteza, o que pode ser comprovado examinando-se os numerosos braços dágua em que se divide o rio $\mathrm{Pi}-$ racicaba, quando atinge a crista da cachoeira, onde se encontram grandes quantidades de caules de Apinagia, orientados segundo aquelas direções. A curvatura dos caules está sempre voltada contra a direção da água. As extremidades frondiformes, ramulosas e capiláceo-multifendidas (Figs. 1-2-a) também se desprendem, nessa época, ficando os caules com as pontas nuas.

Com a acentuação da baixa do rio, em fins de Maio, o número de rochas expostas aumentou; algumas, mormente as mais salientes, chegaram a perder completamente o contacto com a correnteza. Em conseqüência da constante exposição ?o ar, as plantas de Apinagia Accorsii Toledo perderam totalmente os caules, permanecendo sôbre a superfície das pedras apenas as placas rizomatosas, que oferecem, nesse estado, grande semelhança com incrustações liquênicas.

Os rizomas expostos pouco a pouco vão sendo destruidos, por causa da ação dos raios solares e do dessecamento cont1nuo a que estão sujeitos; percebe-se tal fase de decomposição, pela mudança de côr do rizoma que, a princípio, é verde-escuro, depois, passa a amarelo, e, finalmente, a pardo-marron. Contudo, as flores estão adultas e a porcentagem de frutos é grande. Deduz-se, pois, que as plantas de Apinagia Accorsii Toledo (como as demais Podostemonaceae) teem uma duraçăo condicionada ao periodo da enchente, isto é, ao periodo em que as plantas permanecem submersas.

$\mathrm{O}$ aspecto oferecido pelas rochas um tanto proeminentes e que não perderam o contacto com a água, já é bem outro, pois 


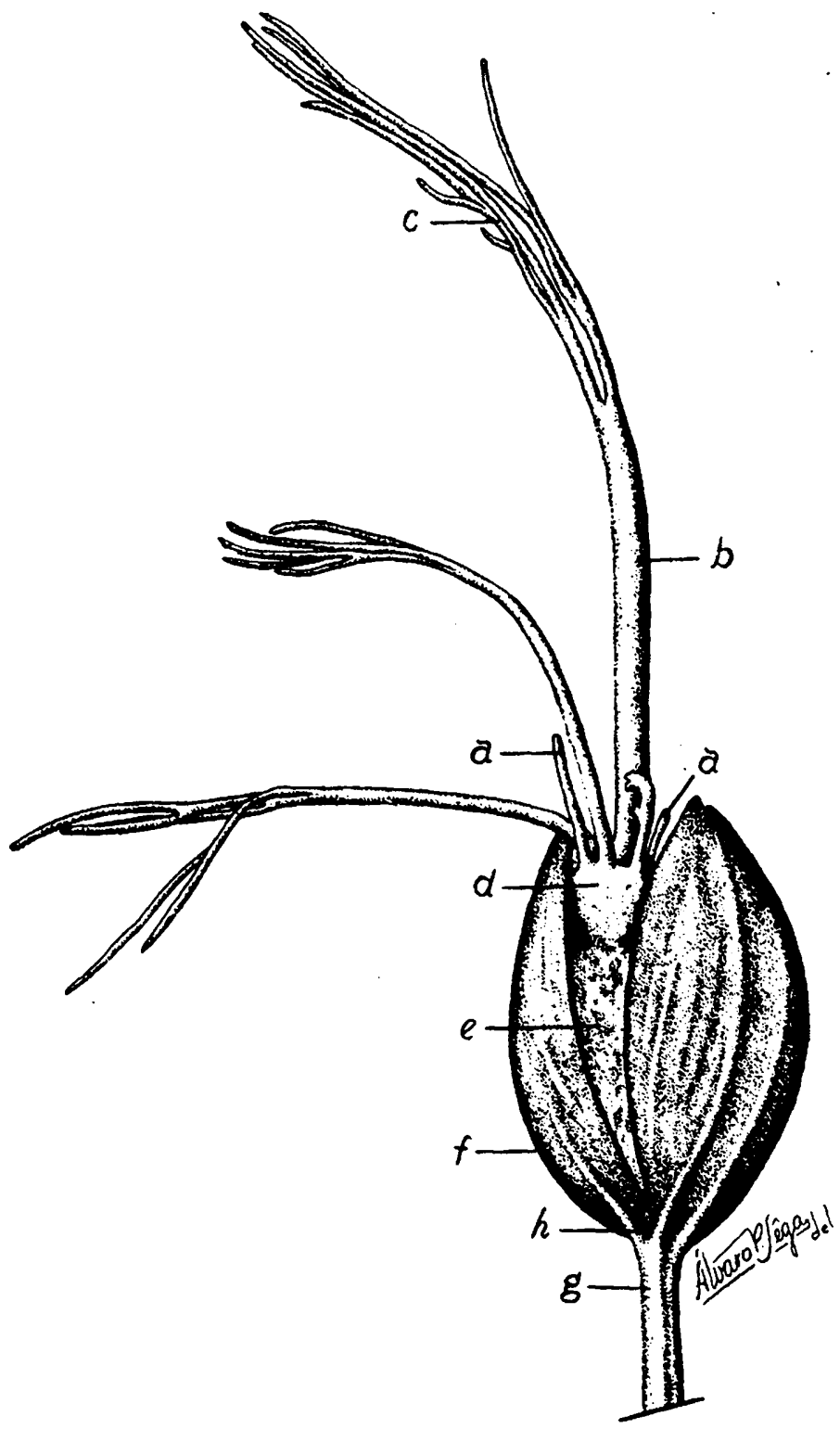

Fig. 11 - Fruto mostrando um "seedling" sôbre a placenta. Aumento $17 \mathrm{X}$. (Original).

a - cotilédones; b - haste principal; c - lacínia capilácea do ramúsculo; d - rizoma jovem; e - placenta; $\mathbf{f}$ - parede da cápsula; g - pedicelo; $\mathrm{h}$ - nervura da cápsula. 
revelam um intenso revestimento de plantas, com seus caules arqueados, embora existam vários claros no conjunto, devido à queda de alguns caules. O contraste revelado entre as rochas completamente sêcas e as que ainda são banhadas ligeiramente pelas águas é enorme, a-pesar-de as plantas terem pràticamente a mesma idade e o mesmo desenvolvimento. A duração das últimas continuará até que, pela baixa mais acentuada dais águas, venham a se expôr completamente, e, então, sofrerão igual comportamento assinalado para as primeiras. Finalmente, as rochas que formam o leito de largos braços dágua, cuja velocidade ainda é grande, mostram um denso revestimento de plantas de Apinagia submersas que, por sua vez, estão perdendo seus caules, tais quais as outras. Parece provável que a que.. da dos caules, por dilaceração dos tecidos, esteja ligada, também, à duração da planta, porque ela se verifica numa éposa em que as condiçőes mesológicas se tornaram desfavoráveis ao seu desenvolvimento.

Ademais, as plantas de Apinagia Accorsii Toledo já completaram, nessa ocasiāo, seu ciclo vegetativo, estando algumas em pleno período de florescimento e mesmo de frutificação, de sorte que, a perpetuação da espécie por meio de sementes está assegurada.

Placas rizomatosas desprovidas de caules, mas formando superficies apreciáveis, podem ser fàcilmente observadas por transparência, em certos canais do salto, onde o volume dágua é pouco espêsso, porém, com arejamento e velocidade suficientes. Entretanto, com a posterior baixa do rio e consequiente diminuição do arejamento, velocidade e quantidade dágua, no canal considerado, as próprias placas rizomatosas já sem caules, entraram em desintegração, sem que se desenvolvessem, primeiramente, as suas gemas floriferas. Tal comportamento é idêntico ao que se obtém, quando se pretende corservar os rizomas em laboratório, embora submersos e sob a ação da água corrente.

Nas plantas submersas, as gemas floriferas ainda não desabrocharam, ao passo que os individuos parcialmente expostos já s̃ encontram em plena fase de frutificação.

Em 16-6-944, o aspecto das plantas de Apinagia Accorsii Toiedo, ainda sob o alcance das águas, está mais modificado, porque agora os claros notados na vegetação são mais pronunciados, por causa do acentuado desprendimento dos caules. por essa razão que já apareceram numerosas superfícies rizomáticas nuas, isto é, despidas completamente de caules. Outra parte dos caules está deitada sôbre os rizomas, ou, então, 
se mantêm recurvados, em forma de arco; nas faces verticais de algumas rochas, os caules estão em posição pendente. Os caules, em geral, já não possuem ramúscılos laciniados, estando reduzidos ao segmento principal e a alguns secundários. $O$ fato é que a queda dos caules se torna cada vez mais acentuada, principalmente nas plantas que se afastaram do seu habitat natural. Todavia, muitas ostentam, ainda, aspecto normal, exibindo um belo conjunto de caules, mas, à medida que as condições mesológicas se forem transformando, com a diminuição contínua do nivel dágua ,elas irão perdendo, também, seus caules e, mais tarde, o próprio rizoma se destruirá, por ocasião da sua permanência ao ar e sob a ação solar. Os caules flutuantes das plantas de Apinagia submersas e situadas no declive, estão como que podados, reduzidos ao segmento principal e aos dois imediatos. Em outros lugares, entretanto, como nos leitos de pedra dos diversos canais já assinalados neste trabalho, em que a água tem uma espessura de poucos centimetros, as extensas superficies rizomáticas estão completamente despidas de caules, percebendo-se, ainda, pela diferença de côr, pequenas áreas correspondentes à queda recente dos mesmos. Das observações supra conclue-se que a queda dos caules é parcial ou total; é um fenômeno geral na espécie em questão, e que se realiza após o completo desenvolvimento vegetativo, estando diretamente relacionado à idade da planta e ao fator água, o qual age no sentido de acelerar o referido desprendimento. lógico que as plantas que se transferiram quase bruscamente do meio aquático para o meio sêco, em virtude da baixa constante do rịo, perderäo seus caules por dessecamento e posterior destruição por decomposição, inclusive o próprio rizoma.

Os rizomas despidos dos seus caules e fora do alcance direto da correnteza, embora constantemente umidecidos, já se encontram em franco periodo de florescimento e mesmo de frutificação, ao passo que os que permaneceram submersos ainda trazem suas gemas fechadas. Entrementes, com a exposição ao ar, devido à baixa do rio, as gemas floriferas vão entrando em atividade. Tal comportamento pode ser atestado examinando-se os flancos de pedra dos inúmeros braços dágua, onde os rizomas expostos ao ar estão floridos e os submersos, não.

Depreende-se que o fator água impede ou dificulta o desabrochamento das gemas floriferas. Enormes superfícies rizomáticas, em que metade está submersa e metade exposta ao ar, confirmam o fato supra, pois a parte exposta está em florescimento, enquanto que a submersa, não. Tôda a superfície 


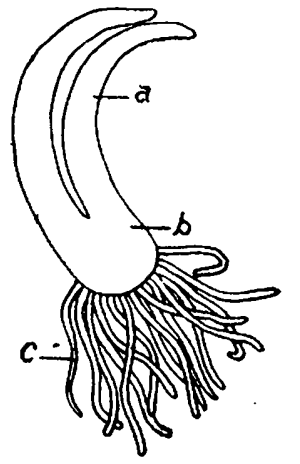

Fig. 12 - Seedling jovem, encontrado sôbre a placenta; muito aumentado. (Original).. a cotilédones; $\mathrm{b}$ - hipocótilo; $\mathrm{c}$ pêlos absorventes

do salto está coberta de enormes quantidades de detritos, sujeiras, restos de árvores, em larga escala, material esse que fica retido, em parte, por causa dos caules de Apinagia, Mniopsis e Tristicha, sôbre os quais se acumula.

No trecho que se segue à queda, já se notam enormes blocos de pedra aflorando, cujas superficies, antes literalmente recobertas de plantas de Apinagia com abundante produção de caules, mostram, agora, o tópo exposto com placas rizomatosas, enquanto que as plantas providas de caules se restringem às partes que ainda estão ao alcance das águas.

Em outro setor do salto, com certa superfície de rochas expostas, mesmo no trecho do declive, os rizomas de Apinagia Accorsii Toledo estão se dessecando, em consequiencia da prolongada permanência fora do seu habitat. Esse aspecto é visivel mesmo à distância, porque os rizomas, de verdes que são, passam a um verde-amarelo, e adquirem, depois, uma tonalidade chocolate. Contudo, já produziram frutos, os quais, presos às rochas, se encarregarão de cooperar na perpetuaçảo da espécie "in loco", quando as condições propícias de novo se apresentarem.

A duração vegetativa das plantas de Apinagia Accorsii Toledo, Mniopsis Glazioviana Warmg. e Tristicha hypnoides (St. Hil.) Spreng var. Hilarii Tul., está intimamente ligada à presença do fator água, como plantas aquáticas que são, de sorte que, uma vez expostas ao ar, começam a sofrer o processo de dessecação que lhes pode causar a morte, se a permanéncia na atmosfera fôr muito prolongada. Todo o desenvolvimento vegetativo se processa durante o periodo de enchente, conforme ficou assinalado, bem como a formação de gemas floriferas. 
Para completar as observações que venho fazendo sôbre as Podostemonaceae do salto de Piracicaba, realizei, em 19-6-944, uma detalhada excursão, a pé, numa grande extensão do leito rochoso do rio, logo abaixo da ponte, até chegar ao local do declive. Embora as águas estivessem baixas, encontrei certas dificuldades para vencer a sua resistência, em virtude das várias correntezas e dos múltiplos acidentes naturais.

Todo o trato do rio situado antes da queda dágua, mostra suas rochas literalmente cobertas por um denso revestimento de Mniopsis Glazioviana Warmg. em plena fase de florescimento: todavia, sòmente as formações vegetais das rochas expostas, isto é, em contacto com a atmosfera, é que mostravam grande porcentagem de flores desabrochadas (vide desenhos), permanecendo, ainda, nas espatelas, as flores das plantas submersas. Para a espécie Mniopsis Glazioviana Warmg., como em Apinagia Accorsii Toledo, o fator água parece exercer certo contrôle sôbre o crescimento das flores, o qual só se completa quando as plantas estiverem fora dágua, conforme investigações feitas em centenas de rochas, em contacto com a atmosfera.

\section{DESSECAÇAO DOS RIZOMAS}

A quantidade de individuos de Apinagia expostos é grande, de modo que, nessa região do salto, o número de rizomas, em vários estados de dessecamento é enorme, encontrando-se, mesmo, tôdas as fases que vão desde o rizoma inalterado morfologicamente, até o seu desaparecimento completo, por destruição e dessecação. Fica, no estágio final da dessecação, sobre a superfície da rocha, uma placa marron chocolate, com o contôrno do rizoma. A placa, por seli turno, também desaparece com o tempo, de sorte que a presença dos frutos pedicelados, fixados fortemente à rocha, é que pode indicar o local onde se desenvolverram as plantas de Apinagia Accorsii Toledo. Antes que se dê o desaparecimento completo do rizoma, ficam assegurados o desenvolvimento das flores e a conseqüente formação de frutos. Ademais, assim que o rizoma começa a ter contacto com a atmosfera, as flores entram imediatamente em desenvolvimento mais acentuado (por deixar de atuar o fator água, inibidor do desenvolvimento das gemas e flores) de modo que há tempo suficiente para que tocos os processos fisiológicos referentes ao periodo de floração e frutificação se completem.

O dessecamento do rizoma expostn ao ar é óbvio, por várias razões: em primeiro lugar, sendo um órgão adaptado ex- 
clusivamente à vida submersa (água), possui uma estrutura tôda própria que lhe permite viver, normalmente, em tal meio. Desta maneira, quando o rizoma passa para o meio sêco, êle perderá, continuamente, água, por falta de dispositivos adequados à sua proteção. evidente que a passagem do meio aquático ao meio sêco năo se faz bruscamente, pois a baixa do rio é um processo lento e depende do regime de chuvas que vigorar durante a época de estiagem. Todavia, mesmo quando as chuvas se reduzem ao mínimo nesse período, como está acontecendo neste ano, a baixa do nível dágua se faz lentamente, permitindo a passagem gradativa do rizoma de um meio a outro. durante êsse período de transiçăo que se dá o rápido desenvolvimento das flores, a polinização, fertilização, frutificaçăo, isto é, todo o ciclo floral, etc.. Em segundo lugar, a ação da luz solar se torna cada vez mais importante, no processo de dessecamento dos rizomas que estão emergindo da água, quer pela incidência direta sóbre éles, durante várias horas no dia, quer pelo aquecimento das rochas, as quais, pela quantidade de calor que retêm, desempenhariam o papel de verdadeiros secadores. Deste modo se opera o dessecamnto dos rizomas, fenómeno que será tanto mais rápido quanto mais tempo permanecerem sob as condições do ambiente externo (sêco).

\section{POLINIZAÇAO}

Conforme referências feitas no capitulo correspondente, o número de flores em cada gema varia de 3 a 8 , estando cada uma revestida de uma espatela (Figs. 6-7) que, por sua vez, se dilacera (Fig. 8-f) quando se iniciar o desenvolvimento das flores, aos primeiros contactos com a atmosfera. Como em Mniopsis Glazioviana Warmg. e, possivelmente, em Tristicha hypnoides (faltam-me observações sôbre esta espécie), a polinização se dá em plena atmosfera, quando as anteras enxutas e suficientemente dessecadas sofrem a deiscência longitudinal. Os grãos de pólen se apresentam ligeiramente tetraédricos, aproximando-se, contudo, da forma esférica. A exina é lisa e mostra, em geral, trés poros. A polinizaçāo é direta, porque as flores são hermafroditas, e em virtude, também, da proximidade e da posição das anteras, em presença do estigma, condição essa decorrente do contacto intimo que os órgãos sexuais sempre tiveram durante a fase em que permaneceram no interior do. espatela. Intervém, ainda, no caso presente, a açāo da gravidade, porque as flores reunidas possuem seus pedicelos florais com tamanhos diferentes, facilitando a queda do pólen 
sôbre o estigma da flor subjacente. Finalmente, parece que a anemofilia pode ser, também, invocada, embora em pequena escala, tal como para o Mniopsis Glazioviana.

\section{3 - MNIOPSIS GLAZIOVIANA WARMG.}

Em 9 de Dezembro de 1943, examinando a face vertical de uma grande rocha, bem exposta ao ar, voltada para o nascente, notei, na parte banhada constantemente pela correnteza, extensas formações de plantinhas de Mniopsis Glazioviana Warmg. provenientes de sementes, ao lado de inúmeros frutos de pedicelos curtíssimos, a-ponto-de a cápsula tocar a superficie da pedra. Os frutos colhidos continham, em seu interior, sementes em germinação (Fig. 15). As plantinhas apresentavam a organização já descrita para o Mniopsis, isto é, são constituidas de uma raiz hemicilindrica (dorsiventral), aderente à pedra, de côr verde, trazendo em seus flancos uma série regular de produções foliares. Na extremidade da raiz percebese, nitidamente, a coifa (Fig. 17). A porção da rocha que nâo recebia água, a-pesar-de possuir grande quantidade de frutinhos, não apresentava nenhuma plantinha. Na face horizontal de uma rocha vizinha e constantemente banhada pela correnteza, havia muitas plantinhas em desenvolvimento, a par de alguns frutinhos.

O material colhido no local citado era constituido, além de frutos, "seedlings", (Fig. 16), partes vegetativas, (Fig. 13-B), de restos de Mniopsis que ali viveram, etc., de permeio com filamentos de algas. Alguns frutos exibiam notável quantidade de "seedlings" em sua superfície, atestando que as sementes germinaram em seu interior. Em outros frutos que sofreram a deiscéncia, o opérculo (o fruto se compõe de 2 opérculos ligeiramente desiguais, sendo um, persistente), preso ao pedicelo, trazia em seu interior, certo numero de "seedlings". Na superfície de algumas cápsulas, ainda fechadas, havia elevado número de "seedlings", ao lado dos restos dos tegumentos das sementes (Fig. 14); estas, naturalmente, foram ali levadas pela própria água. Finalmente, notei grande número de "seedlings" sóbre restos de raminhos velhos e de fólhas mortas.

\section{PLACENTA}

Os frutos de Mniopsis possuem uma placenta ovóide, que se assemelha, pela inserção e textura, aquela de Apinagia. Nas anfratuosidades de sua superficie implantam-se numerosas e 
diminutas sementes. A coloração da placenta é verde, devido à presença de inúmeros cloroplastídeos, ligeiramente esféricos, existentes nas células do parênquima que a constitui. Sôbre os cloroplastídeos puderam ser identificados grânulos de amido.

\section{SEMENTES}

São ovóides, de côr marron. Suas dimensões sāo:

Eixo maior: 230 micra.

Eixo menor: 180 micra.

\section{EMBRIAO}

Os embriōes, examinados ao microscópio, revelaram a presença do pincel de pêlos absorventes, cujo papel é idêntico ao assinalados para a Apinagia, isto é, funcionam como haustorios, quando os "seedlings" crescem sóbre a placenta e, como elementos de fixação, se os "seedlings" se desenvolvem sôbre o substrato exterior. Confirmando essa hipótese, existem numerosos exemplos de "seedlings" bem desenvolvidos, aderentes ao substrato, desprovidos de pêlos, sendo a região a êles correśpondentes achatada e de uma coloraçăo pardacenta. Talvez, os pélos sejam destinados mais para a fixação do que para a função de absorção, pois que os "seedlings" são verdes desde as suas primeiras fases de desenvolvimento, podendo, no meio

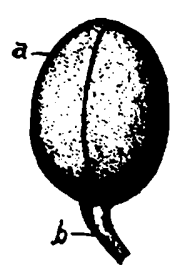

A

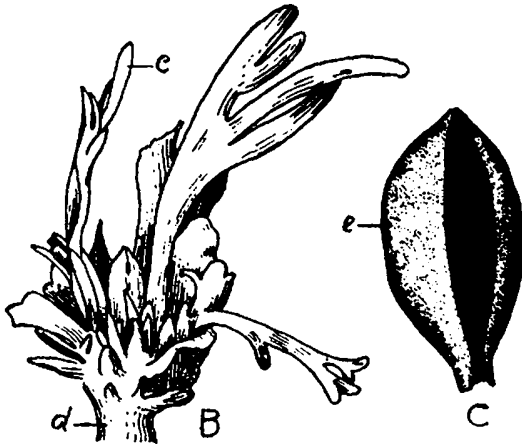

C

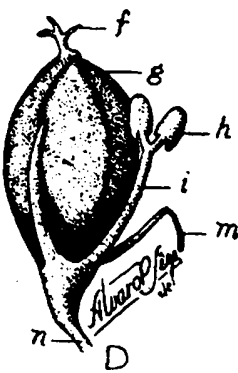

Fig. 13 - Fruto (A); aumento $10 \mathrm{X}$. Parte vegetativa (B); aumento $3 \mathrm{X}$. Espatela (C); aumento $12,5 \mathrm{X}$. Flor nova (D); aumento $12,5 \mathrm{X}$.

at - parede de iruto; b - peelicelo do fruto; $c$ - folha; d - ramo: eespatela jsolada; e - estigma: g - ovirio; h - anteris; i - filètc; $m$ - tépalas membranáceas. 
aquático onde vivem, realizar a fotossintese. No mais, o aspecto e a constituição morfológica do embrião são semelhantes aos de Apinagia, razão por que deixo de entrar em descrição detalhada.

Acompanhei, também, o comportamento e o desenvolvimento vegetativo da espécie de Mniopsis Glazioviana Warmg., no mesmo periodo em que foram observadas as plantas de Apinagia Accorsii Toledo e verifiquei, então, que durante a fase de submersão (período de enchente) houve notável crescimento vegetativo, com formação de ramos, fôlhas botões blorais. A produção de raizes ainda continua, o que significa nova formação de "núcleos" de Mniopsis, destinados a ampliar a sua distribuição local.

A espécie Mniopsis Glazioviana Warmg. emite, de plantas já adultas, raízes com aspecto de cordões hemicilíndricos providos de uma goteira na face em contacto com a superficie de pedra; tais como nos estolhos de Apinagia, inúmeros rebentos (formações rađicais), aos pares, se dispōem em ordem crescente, a partir da extremidade da raiz. Entretanto, em Mniopsis, cada rebento já desenvolve um grupo de formações foliáceas (produções radicais). A ponta da raiz principal, responsável pela produção de novos individuos, traz uma coifa com aspecto de telha, disposta apenas na face superior; a coifa tem contacto com a extremidade da raiz sòmente por uma pequena superfície, enquanto que sua região posterior é livre e um tanto alevantada, de sorte que faz, com ela, um ângulo agudo. (Fig. 17).

Portanto, as espécies Mniopsis Glazioviana e Apinagia Accorsii, se propagam vegetativamente por meio de raizes e estolhos, respectivamente.

O periodo de florescimento e frutificação ocorre paralelamente ao de Apinagia, de vez que as duas espécies vivem quase que associadas no mesmo local, estando submetidas, portanto, à ação dos mesmos fatores.

As plantinhas de Mniopsis que se encontram expostas na atmosfera, portanto, sob a ação direta dos raios solares, estāo perecendo; a princípio, começam por ficar amarelas e, depois, suas fôlhas murchas se destacam, restando, no final, os raminhos que sustentam os frutinhos pedicelados, aderentes à rocha. Mais tarde, a parte vegetativa desaparece completamente, permanecendo, nos respectivos lugares, os frutinhos, como se estivessem implantados na pedra. 


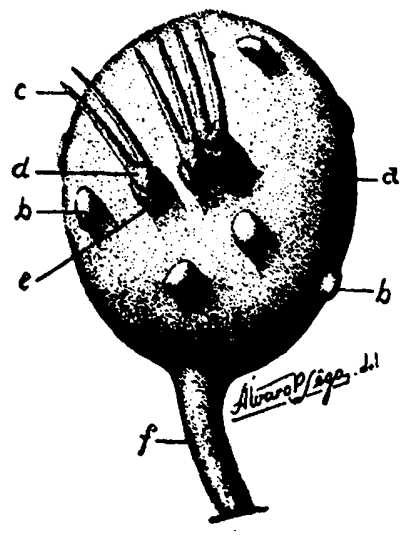

Fig. 14 - Fruto com sementes e "seedlings" desenvolvendo-se sôbre suas paredes; aumento $18 \mathrm{X}$. (Original). a - parede do fruto; $b$ - semente; c - cotilédones; e tegumento da semente; $f-$ pedicelo do truto.

\section{DESCRIÇÃO DOS "SEEDLINGS"}

Entre os restos vegetais acumulados sôbre as formações de Mniopsis Glazioviana foram encontrados numerosos "seedlings" (Fig. 16) fixados ao substrato, por meio de um tufo de pêlos absorventes; contudo, năo pequena é a quantidade de sementes que germinaram no interior dos frutos (Fig. 15), sôbre as paredes das cápsulas (Fig. 14-c, d, e), etc., conforme foi assinalado.

O eixo hipocótilo (158 micra de comprimento), de forma ligeiramente cilindrica, é reduzidissimo em relação aos cotilédones ( 585 micra de comprimento por 180 micra de largura na região média); não se distingue nele diferenciação morfoIógica entre cauliculo e radícula. Da sua extremidade um tanto curva saem numerosos pêlos absorventes (112,5 micra de comprimento) que, no interior do fruto, teriam a propriedade de absorver as reservas contidas no tecido placentário (haustórios) e, no meio exterior, a finalidade de fixar a plantinha ao substrato. Freqüentemente, quando a plantinha já está bem adaptada ao substrato por meio dos pêlos absorventes, o hipocotilo se dilata um pouco na extremidade, assumindo, então, a configuração de um disco (225 micra de largura). Ao hipocótilo, e fazendo corpo com êle, seguem-se os dois longos cotilédones, de aspecto foliáceo, ligeiramente afastados entre si, lembrando, o conjuito, a figura de um peteca. O hipocótilo mede, nessa região um pouco deprimida, 202,5 micra de largura. As extremidades dos cotilédones se afilam ligeiramente (Fig. 16). 
Nesse estado de desenvolvimento, é comum a presença de uma fólha entre os cotilédones, da mesma forma que êles, embora um tanto mais alongada (167 micra de comprimento). Convém salientar que a plantinha é constituida, também, de um tecido fundamental verde, envolvido por uma epiderme, tal como nos "seedlings" de Apinagia Accorsii Toledo.

\section{POLINIZAÇAO}

A deiscência longitudinal das ateras se opera nas flores plenamente desabrochadas (isto é, cujas espatelas já se dilaceraram) na atmosfera e suficientemente sêcas. milhares de pequeninas flores mostram suas anteras esbranquiçadas, devido ao pólen abundante (em relação ao tamanho das flores), que se espalha ao mais leve toque. Examinando numerosas flores nas condições supra, com o auxillio de uma lupa, notei que as anteras abertas estavam deitadas, em grande parte, sóbre o estigma da flor, produzindo-se, assim, a polinizaçāo direta. O contacto natural da antera com o estigma deve-se ao fato de os estames estarem bem encostados ao gineceu, quando a flor ainda se encontra dentro da espatela, de modo que, ao se processar a ruptura desta última, por ocasião do desenvolvimento da flor, na atmosfera, os estames se mantêm por certo tempo, naquela posição, de sorte que, ao se dar a deiscência os grăos de pólen caem sôbre o estigma. A par da polinização direta, é viável, também, que se opere a polinização anemófila, pois que as flores são nuas, hermafroditas e as plantinhas formam associações compactas. A polinização hidrófila está, por natureza, excluida, devido ao fato de que as flores só completam o seu desenvolvimento quando na atmosfera, época favorável à deiscência das anteras, desde que se estabeleçam condições de relativa secura, conquanto estejam nas proximidades da superficie liqüida. Năo notei a presença de insetos nas plantinhas, durante as minhas observações, motivo pelo qual êste fator biológico também está afastado como causa da polinizaçāo. A presença esporádica de alguns insetos no local visitado não é suficiente para admitílos como agentes de polinização. A ventilação que, em geral, se forma na superfície das rochas aquecidas pelos raios solares, pareceme que pode ser levada em conta como fator auxiliar da polinização, facilitando, ao mesmo tempo, o enxugamento das anteras que ainda não se abriram. E natural que a água ,atingindo de leve a superfície do estigma polinizado, só pode favorecer a retenção e a germinação do pólen; é o que acontece em 
algumas flores, cujas plantinhas estão semisubmersas. A área d€ distribuição local de Mniopsis é, pois, vastissima.

A medida que me aproximava da zora do declive, observei progressiva diminuição das formaçōes de Mniopsis Glazioviana e, cada vez mais numerosas, as formações de Apinagia Accorsii. A distribuição local mais intensa de Apinagia Accorsii se circunscreve à massa rochosa que constitui a espaçosa fachada frontal do salto, em tôda a largura, abrangendo, também, as faixas situadas aquém e além da queda dágua; aquí pude apreciar melhor o notável desenvolvimento assumido pelas plantas de Apinagia Accorsii, em virtude da multiplicidade de meios constituidos pelas amplas e variadas superfícies rochosas, algumas, submersas, outras, semisubmersas, e intei-

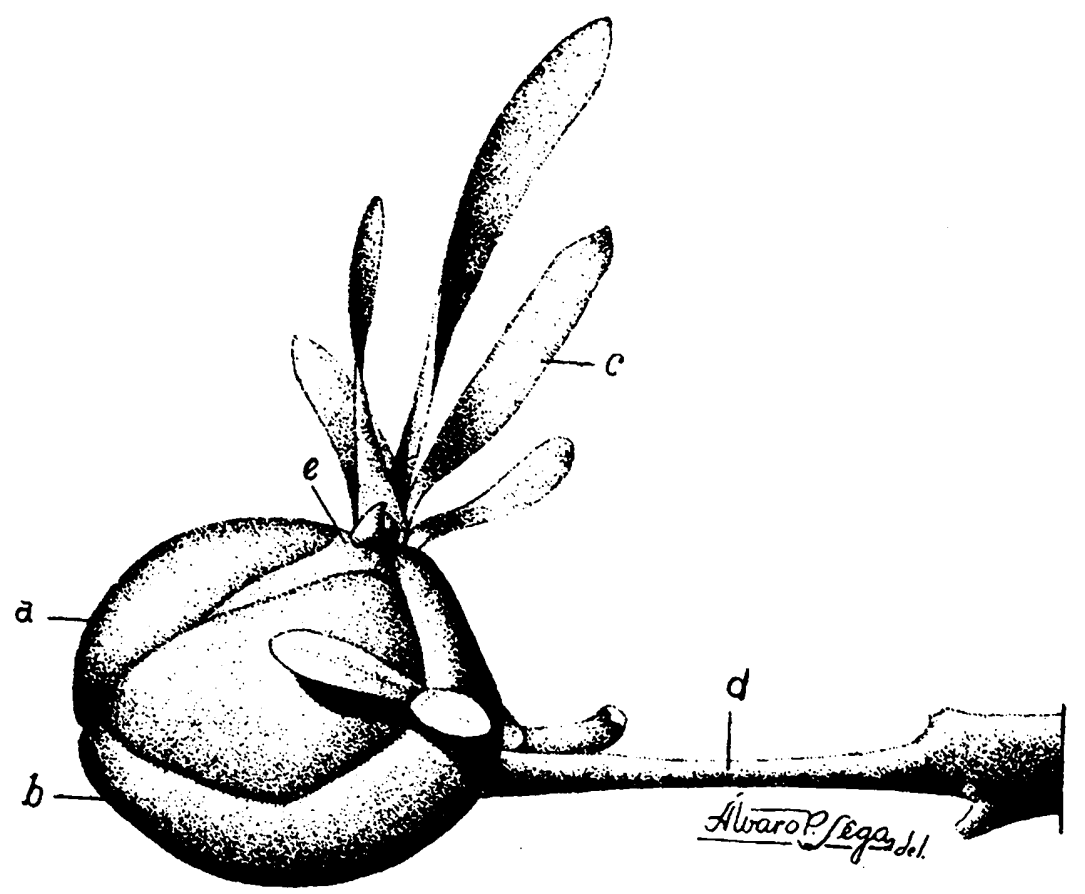

Fig. 15 - Fruto mostrando um "seedling" em desenvolvimento na placenta, cuja raiz, provida de produções foliáceas, contorna parte da cápsula; aumento $19 \mathrm{X}$. (Original).

a - parede da cápsula; b - raiz aderente à parede da cápsula; c - fôlhas novas. 
ramente expostas, outras. A configuração assumida pelos rizomas expostos, na sua quase totalidade sem caules, depende muito da natureza da superfície onde êles se desenvolvem e do número de indivíduos, se crescem associados ou isolados, isto é ,independentes. Poucas são as plantas que ainda trazem caules, apenas as que estão ainda submersas. Em geral, quando isolados e em superficies planas, os rizomas assumem 0 aspecto ligeiramente elíptico, com dimensões variáveis, tais como: $20 \times 25 \mathrm{cms}$., $30 \times 30 \mathrm{cms}$., etc., mostrando bem dispostas as suas ramificações curtas e sinuosas. Se êles formam associações, então oferecem um contôrno e amplitude variáveis, de acôrdo com o número de individuos reunidos.

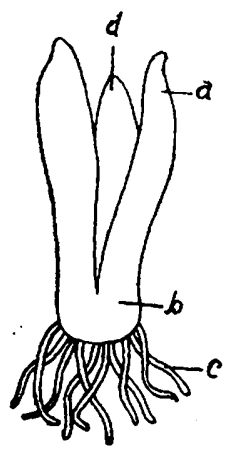

Fiæ. 16 - "See-
dling" jovem, en-
contrado no inte-
rior do fruto;
muito aumentado.
(Original).
a - cotilédone;
b-hipocótilo; c-
pêlos absorventes.

Confirma-se, aqui, a observaçāo feita no lugar sito junto to paderão, com respeito à floração, isto é, que os rizomas em contacto com a atmosfera estão com suas gemas floriferas em vários estados de abertura, e, o florescimento, em pleno desenvolvimento, havendo, também, boa porcentagem de frutos. Todos êsses estágios evolutivos se observam num mesmo rizoma. Os rizomas que possuem parte de sua superfície fora dágua e outra ainda submersa, apresentam flores e frutos na parte exposta.

A autor agradece ao sr. Alvaro P. Sega, a execução dos desenhos que ilustram esta contribuição, os quais foram baseados em material vivo. 


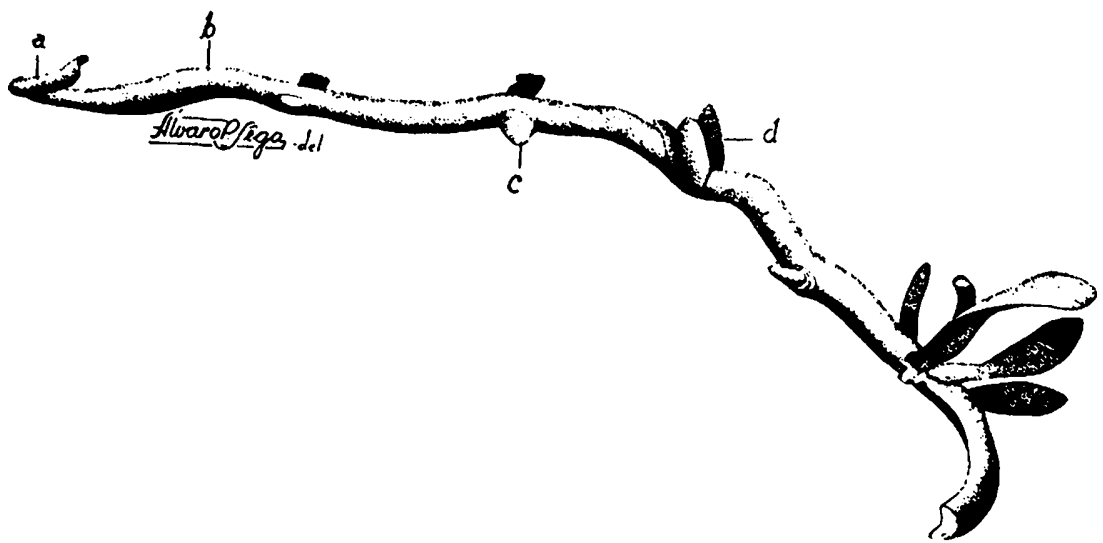

Fig. 17 - Raiz em pleno desenvolvimento; aumento 3,5 X. (Original). a - coifa; b - raiz; c, d, - formaçōes foliáceas provenientes de gemas radicais.

\section{4 - RESUMO E CONCLUSOES}

O Autor estuda, nesta contribuição, os aspectos biológicos e ecológicos das plantas Apinagia Accorsii Toledo nov. esp. e Mniopsis Glazioviana Warmg., Podostemonaceae que vivem incrustadas nas rochas do salto do rio Piracicaba, situado em frente à cidade de igual nome.

Refere-se, principalmente, à especie Apinagia Accorsii Toledo, por mostrar grande transformação de tôda a parte vegetativa, ao lado de inúmeros caracteres de regressão, como: redução do sistema condutor, ausência de estômatos, simplificação da estrutura dos caules e das fôlhas, preponderância da multiplicação vegetativa, etc.. Entretanto, pôe em paralelo as principais modificações e produçōes apresentadas por ambas as espécies, sob a variação dos fatores ambientais, no decurso de pouco mais de um ano, período em que se processaram os ciclos vegetativo e floral.

Durante o periodo de baixa do rio, as rochas, completa ou parcialmente expostas ao ar, se achavam recobertas de plantas de ambas as espécies, que exibiam notável desenvolvimento vegetativo, formado enquanto permaneceram submersas. Por essa razão poude ser avaliado o comportamento das plantas, quer as expostas na atmosfera, quer as submersas e, ainda, das que participaram de um ambiente intermediário, isto é, 
parte ao ar e parte sob as águas. As plantas que permaneceram inteiramente a descoberto mostravam, como é natural, alterações, devido à dessecaçāo (a perda de água é por evaporação porque as plantas não possuem a menor proteção contra a transpiração) e da ação dos raios solares. Dest'arte, os rizomas de Apinagia Accorsii se apresentavam dessecados, porém, exibiam abundantes formações de frutos, semelhantes a esporocarpos de musgos. As plantas umidecidas por contínuos jactos dágua, embora expostas à atmosfera, tinham seus rizomas verdes, com aspecto de talos de hepáticas, providos de numerosas gemas floriferas e flores em vários estágios de desenvolvimento; todavia, mostravam poucos caules adultos e em formação; existiam, ainda, numerosas placas rizomatosas nuas. Finalmente, os rizomas situados na regiāo do declive (água velocíssima e arejamento intenso) exibiam densas formaçōes de caules adultos e ramificados; a curvatura da haste principal voltava-se contra a correnteza; não possuiam flores e nem frutos.

A área local de distribuição da espécie Mniopsis Glazioviana Warmg. situa-se acima da cachoeira; na região da queda dágua poucas são as rochas que apresentam exemplares de Mniopsis.

A conservação de ambas as espécies fora do seu habitat não é possivel, mesmo que as plantas se conservem sóbre as pedras e se renove diariamente a água.

Após a destruição da parte vegetativa de Mniopsis, ficam gravados sóbre as rochas os vestígios das plantinhas, em forma de faixas esbranquiçadas, estreitas, longas, ostentando aquí e acolá séries de frutinhos marrons menores que os de Apinagia, de forma esférica e curtamente pedicelados.

Das observações feitas conclue-se que:

1 - as plantas submersas e sob a ação de fortes correntezas, bem arejadas, desenvolvem os órgãos vegetativos;

2 - as plantas semiexpostas a atmosfera mostram, na parte do rizoma que está fora dágua, gemas floríferas em vários estágios de abertura, flores e frutos;

3 - as plantas completamente a descoberto exibem flores e frutos; a parte vegetativa está condenada à morte, porque sujeita à evaporação e à ação solar.

Fora do habitat as plantas paralisam o seu crescimento vegetativo (e não poderia ser de outra forma, pois deixam de 
viver no seu meio natural) ativando-se, sobremodo, o desenvolvimento floral e a consequiente formação de frutos.

Iniciada a enchente, as plantas vão, aos poucos, submergindo; nota-se, então, intenso crescimento de tôda a parte vegetativa, fato êsse que poude ser verificado em consequiencia de uma estiagem, quando as plantas vieram à tôna e revelaram o extraordinário desenvolvimento que alcançaram, tanto em rizomas quanto em produção de caules.

Os rizomas de Apinagia produzem estolhos que se encarregam de aumentar o número de individuos. Os estolhos são cordões hemicilindricos, aderentes à superfície das rochas e emitem, lateral e alternadamente, novos rizomas, de tamanhos crescentes, a partir da extremidade. Sôbre os jovens rizomas já se notam caules em desenvolvimento. A medida que os rizomas recém-formados aumentam de tamanho, vão se desprendendo dos estolhos e passam a desenvolver-se normalmente sôbre as pedras. As plantinhas de Mniopsis Glazioviana Warmg. produzem, ao invés, raízes hemicilíndricas, aderentes ao substrato; em sua extremidade, e na face superior, dispõese a coifa, presa apenas por um ponto.

Dos flancos das raizes se originam formações foliáceas, provenientes de gemas radicais.

Conforme foi assinalado, a frutificação se processa em épocas diferentes, porque o desenvolvimento das flores e a consequiente fecundação se realizam na atmosfera. Por êsse motivo, há, no habitat, frutos com tôdas as idades e, por conseguinte, sementes em diversos graus de maturação. Por ocasiáo da enchente, a germinação pode operar-se sôbre a placenta de frutos parcialmente abertos, na parede interna e externa das cápsulas e, finalmente, nos residuos de rizomas. O embrião de Apinagia é microscópico, em forma de $\mathbf{U}$, cujos ramos pontudos são os cotilédones; a radícula e o caulículo são indistintos. Por ocasião da germinação da semente, o embrião já é bem clorofilado, podendo realizar, pois, a fotossintese. o embriāo de Mniopsis só difere do de Apinagia apenas na forma; no mais, comporta-se de modo idêntico.

Os "seedlings" possuem, desde os primeiros estágios de desenvolvimento, um tufo de pêlos absorventes revestindo a extremidade do hipocótilo, cuja finalidade principal parece ser a de fixação. Nessa fase êles conservam, ainda, a forma de $\mathbf{U}$ do embrião.

No caso de a semente germinar sôbre a placenta, conforme atestam os exemplos encontrados, as reservas nutritivas contidas no tecido placentário podem ser utilizadas pelos "see- 
dlings. Se as plantinhas se desenvolvem no interior dos frutos ou em sua superficie externa, a passagem para a rocha se dará em consequiência do aumento de pêso, decorrente do crescimento vegetativo, de sorte que o pedicelo, já flexivel pela ação da água, se curva, pondo a cápsula sôbre a pedra; feito êsse contacto, observado em numerosos exemplos, o rizoma fàcilmente se incrustará na rocha.

As placentas ovóides, constituidas de parênquima clorofilado quando novas, mostram-se, na maturidade, esbranquiçadas por causa das reservas amiláceas. Os grăos de amido podem ser simples ou compostos; a forma é um pouco variável, dominando, porém, a lenticular.

Os novos rizomas de Apinagia, formados durante a fase de enchente, possuem caules e gemas floriferas; estas abrigam de 3 a 8 flores, cada qual coberta por uma espatela. As gemas estão embutidas no seio do rizoma e são protegidas externamente por duas escamas embricadas. O desabrochar das gemas se dá em plena atmosfera, quando as escamas se afastam para dar passagem às flores. Sobrevindo o período de baixa do rio, os caules de Apinagia vão de desprendendo aos poucos, em consequiência da prolongada vibração a que estiveram submetidos, enquanto submersos, devido à intensa velocidade e pressão dágua. Em geral, o desprendimento se dá junto à inserção no rizoma; todavia, a ruptura pode realizar-se um pouco acima dêste, de modo a formarem-se pequenos tocos de caules. Os caules, antes da queda, perdem as suas extremidades frondiformes e capiláceo-multifendidas. Sôbre os rizomas ficam as cicatrizes correspondentes aos caules que se desprenderam.

A duração, pois, dos órgãos vegetativos de ambas as espécies está condicionada, lơgicamente, ao fator água, porque, uma vez expostas na atmosfera por muito tempo e sob a ação dos raios solares, a morte das plantas sobrevirá. Contudo, deve-se levar em conta a velocidade e o grau de arejamento da água, pois foram encontradas inúmeras plantas submersas em lugares desprovidos dos fatores assinalados e que sofreram, também, o processo de desintegração.

A medida que os rizomas cheios de gemas floriferas e sem caules se forem descobrindo, entram em dessecação, porque estão sujeitos à ação dos fatores do meio externo. Em muitos rizomas forma-se, em conseqüência da dessecação, uma massa pegajosa que se transformará, mais tarde, em crosta delgada sóbre a pedra. Antes, porém, dessa fase final, as gemas se desenvolvem, as flores se expandem na atmosfera, e, após a polinização e conseqüente fertilização, surgirão os frutos que per- 
manecerão fixos à rocha; no próximo periodo de enchente as sementes germinarão nos meios apontados, garantindo, assim, a perpetuação da espécie no habitat.

A polinização de ambas as espécies, de acôrdo com as observações feitas, é direta, realizando-se em plena atmosfera, quando as anteras enxutas e suficientemente dessecadas sofrem a deiscência, libertando o pólen.

A espécie Mniopsis Glazioviana Warmg. comporta-se de igual modo que Apinagia Accorsii Toledo sob o aspecto referente à açăo entre planta e habitat.

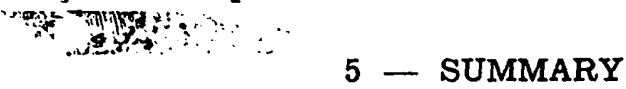

In the present paper biological and ecological studies are made of two Podostemonaceae, namely Apinagia Accorsii Toledo (n. sp.) and Mniopsis Glazioviana Warmg. which live attached to the rocks of Piracicaba's fall. (At Piracicaba, E. de $\mathbf{S}$. Paulo, Brasil).

For revelling great modification in all vegetative parts aside from many regression characters as reduction of the conducting system, absence of stomata, simplification of the structure of the caules and leaves, prevalence of vegetative propagation and so forth special reference is made to Apinanagia Accorsii Toledo.

All the observation refer to a period a little longer than an year, comprising the vegetative and floral cycles.

The local distribution of both the species is the following:

1 - Apinagia Accorsii Toledo in the rocks situated just in the water fall where velocity ad aeration of the liquid are very high.

2 - Mniopsis Glazioviana Warmg. in the rocks some distance upwards in the current.

Out from the water the Podostemonaceae very soon will dry up and die, specially if they are directly under the action of the sun rays.

The plants flowrish and fructify only when in contact with the air. Pollinization is direct. Notwithstanding the complete destruction of the whole vegetative part due to a prolonged exposition to the air (in the dry period) the fruits attach themselves to the rocks by means of a pedicel.

In Apinagia Accorsii the buds having from 3 to 8 flowers are embedded in a flat rhizome. Externally they are recovered 
with two imbricate scales. The rhizomes of Apinagia give rise to transitory caules of frondiform nature ramified and terminated by many capillaceous lacinias. After the detachament of the caules the corresponding scars can be seen on the rhizomes.

The vegetative propagation of Apinagia is performed by hemicyllindrical stolons attached to the surface of the rocks, which by a process of tuberization produce laterally and alternatelly new rhizomes disposed in an increasing order up from the extremity.

The plants of Mniopsis, on the contrary, produce hemicyllindrical roots from whose flanks radicular buds give rise to folliaceous formations disposed into pairs.

According to our observation the proper means for seed germination are:

1 - The placent of parcially open fruits.

2 - The external and internal walls of the open capsules.

3 - The pedicel of the fruits, the rest os Apinagia's rhizomes and finally vegetative residues of Mniopsis.

The embryo, charged with chrorophyll at the time of germination of the seeds, is a microscopical structure provided with two long cotyledons. The radicule and caulicule are indistinct. In the seedlings the extremity of the hypocotyl develops a fascicle of unicellular hairs, whose principal function seems to be fixation.

Due to the weight of the fruit and the flexibility of the pedicel the capsules charged with the seedlings establish, under the action of the flow, contact with the rock's surface thus allowing the young plants to attach themselves more and more to their definitive substratum.

\section{6 - BIBLIOGRAFIA CONSULTADA}

1 - CAMINHOA, J. M. - 1877. Elementos de Botanica Geral e Medica. Pg. 2939. Tipografia Nacional ‥ Rio de Janeiro.

2 - GOLA, NEGRI E CAPPELLETTI - 1936. Trattato di Botanica. Pg. 850. Ed. Italiana Unione Tipografico - Editrice Torinese - Torino.

3 - LUBIMENKO, V. N. - 1928. Traité de Botanique Généra- 
le. 2. ${ }^{\circ}$ Vol. Pg. 1003. Trad. do Russo p. Mlle Anna Joukov. Gauthier-Villars et Cie. Editeurs. Paris.

4 - MARTIUS, C. F. PH. - 1872-1873. Flora Brasiliensis. Vol. IV-Pars. I, Pg. 230. Moachii in Typographia Regia C. Wolf et Fil. et in Offic. Lithograph. S. Minsinger.

5 - WARMING, E - 1901. Sixiéme Mémoire Sur la Famille des Podostemonacées. Memoires de l'Academie Royale des Sciences et lettres de Danemark, Copenhague. 6me. Série, Section de Sciences, t. XI, n. ${ }^{\circ} 1$ - Kobenhavn. 1901.

6 - WARMING, E. - 1882 . Etudes sur la Famille des Podostemonacées. Deuxiéme Mémoire. II - Organes Végétatifs du Castelnavia princeps. Tul. \& Wedd. Kgl. Danske Vidensk. Selsk Skv. 6.a Série. II-3. 1882.

'/ - WETTSTEIN, R. - 1927. Botanica Sistematica. 2.o Vol. Pg. 216. Ed. Italiana. Unione Tipografico-Editrice Torinese. Torino. 